\title{
Design of new acid-activated cell-penetrating peptides for tumor drug delivery
}

Jia Yao $^{1}{ }^{\text {, }}$ Yinyun Ma ${ }^{2}$, Wei Zhang ${ }^{3}$, Li Li ${ }^{2}$, Yun Zhang ${ }^{2}$, Li Zhang ${ }^{2}$, Hui Liu ${ }^{2}$, Jingman Ni ${ }^{\text {Corresp.., }}{ }^{2}$, Rui Wang ${ }^{3}$

1 Lanzhou University, The first Hospital, Lan Zhou, Gansu Province, China

2 Lanzhou University, School of Pharmacy, Lan Zhou, Gansu Province, China

3 Lanzhou University, Key Laboratory of Preclinical Study for New Drugs of Gansu Province, Lan Zhou, Gansu Province, China

Corresponding Author: Jingman Ni

Email address: nijm@lzu.edu.cn

TH(AGYLLGHINLHHLAHL(Aib)HHIL-NH ${ }_{2}$ ), a histidine-rich, cell-penetrating peptide with acidactivated $\mathrm{pH}$ response, designed and synthesized by our group, can effectively target tumor tissues with an acidic extracellular environment. Since the protonating effect of histidine plays a critical role in the acid-activated, cell-penetrating ability of $\mathrm{TH}$, we designed a series of new histidine substituents by introducing electron donating groups (Ethyl, Isopropyl, Butyl) to the $\mathrm{C}-2$ position of histidine. This resulted in an enhanced $\mathrm{pH}$ response and improved the application of TH in tumor-targeted delivery systems. The substituents were further utilized to form the corresponding TH analogs (Ethyl-TH, Isopropyl-TH and Butyl-TH), making them easier to protonate for positive charge in acidic tumor microenvironments. The $\mathrm{pH}$-dependent cellular uptake efficiencies of new TH analogs were further evaluated using flow cytometry and confocal laser scanning microscopy, demonstrating that ethyl-TH and butyl-TH had an optimal pH-response in an acidic environment. Importantly, the new TH analogs exhibited relatively lower toxicity than $\mathrm{TH}$. In addition, these new $\mathrm{TH}$ analogs were linked to the antitumor drug camptothecin (CPT), while butyl-TH modified conjugate presented a remarkably stronger $\mathrm{pH}$-dependent cytotoxicity to cancer cells than TH and the other conjugates. In short, our work opens a new avenue for the development of improved acid-activated, cellpenetrating peptides as efficient anticancer drug delivery vectors. 
1 Design of New acid-activated Cell-penetrating Peptides for Tumor

2 Drug Delivery

3

4 Jia Yao ${ }^{\mathrm{b}, 1}$, Yinyun $\mathrm{Ma}^{\mathrm{a}, 1}$, Wei Zhang ${ }^{\mathrm{c}}$, Li Li ${ }^{\mathrm{a}}$, Yun Zhang ${ }^{\mathrm{a}}$, Li Zhang ${ }^{\mathrm{a}}$, Hui Liu ${ }^{\mathrm{a}}$, Jingman Ni ${ }^{\mathrm{a}}{ }^{*}$

5 Rui Wangc*

6

$7 \quad{ }^{a}$ School of Pharmacy, Lanzhou University, Lanzhou 730000, China

8 bThe first Hospital of Lanzhou University, Lanzhou 730000, China

$9 \quad{ }^{\mathrm{c}}$ Key Laboratory of Preclinical Study for New Drugs of Gansu Province,

10 Lanzhou University, Lanzhou 730000, China

111 These authors contributed equally to this work.

$12 *$ Corresponding author:

13 Jingman, Ni, Ph.D., Chair Professor

14 Address: School of Pharmacy; The first Hospital of Lanzhou University, Lanzhou University, Lanzhou 730000, PR China

16 Tel: +869318915683 ;

Fax: +86931 8911255;

E-mail: nijm@1zu.edu.cn (Jingman Ni) 
22

\section{Abstract}

TH(AGYLLGHINLHHLAHL(Aib)HHIL-NH ${ }_{2}$ ), a histidine-rich, cell-penetrating peptide with acid-activated $\mathrm{pH}$ response, designed and synthesized by our group, can effectively target tumor tissues with an acidic extracellular environment. Since the protonating effect of histidine plays a critical role in the acid-activated cell-penetrating ability of $\mathrm{TH}$ which we designed and synthesized before, we designed a series of new histidine substituents by introducing electron donating groups (Ethyl, Isopropyl, Butyl) to the C-2 position of histidine. This resulted in an enhanced $\mathrm{pH}$-response and improved the application of $\mathrm{TH}$ in tumor-targeted delivery systems. The substituents were further utilized to form the corresponding $\mathrm{TH}$ analogs (Ethyl-TH, Isopropyl-TH and Butyl-TH), making them easier to protonate for positive charge in acidic tumor microenvironments. The $\mathrm{pH}$-dependent cellular uptake efficiencies of new $\mathrm{TH}$ analogs were further evaluated using flow cytometry and confocal laser scanning microscopy, demonstrating that ethyl-TH and butyl-TH had an optimal pH-response in an acidic environment. Importantly, the new $\mathrm{TH}$ analogs exhibited relatively lower toxicity than $\mathrm{TH}$. In addition, these new $\mathrm{TH}$ analogs were linked to the antitumor drug camptothecin (CPT), while butyl-TH modified conjugate presented a remarkably stronger $\mathrm{pH}$-dependent cytotoxicity to cancer cells than TH and the other conjugates. In short, our work opens a new avenue for the development of improved acid-activated, cell-penetrating peptides as efficient anticancer drug delivery vectors.

\section{Introduction}

Cancer is a major socio-economic burden on the society. Chemotherapy is an effective conventional treatment against cancer, however, traditional chemotherapy drawbacks such as limited selectivity, deleterious side effects, and multi-drug resistance, seriously restrict their clinical curative effects (Chari, 2008; Monsuez et al., 2010; Monje \& Dietrich, 2011). Therefore, the development of antitumor drugs with high specificity and diminished side effects remains a 
considerable challenge.

Cell-penetrating peptides (CPPs) are typically short cationic sequences of 10-30 amino acids. Due to the ability to traverse cell membranes, CPPs are widely used in the cellular delivery of proteins (Ana, Wei-Ming \&Chin, 2016 ), plasmid DNA(Kato et al., 2016), oligonucleotides(Helmfors, Eriksson \&Langel, 2015), and liposomes (Huang et al., 2013). Meanwhile, due to their aqueous solubility, and tissue penetration and distribution capabilities, CPPs are also increasingly used for delivery of anticancer drugs (Vivès, Schmidt\& Pèlegrin, 2008; Fonseca, Pereira \&Kelley,2009). Importantly, CPPs have the potential to overcome multidrug resistance (Davoudi et al., 2014; Vargas et al., 2014). When CPPs were coupled to traditional anti-tumor drugs such as paclitaxel (PTX) and podophyllotoxin (PPT), they significantly enhanced drug sensitivity of resistant cancer cell lines (Dubikovskaya et al., 2008; Lindgren et al., 2006). However, their major limitations in delivery applications, including nonspecificity, severe toxicity due to their positive charge, and rapid clearance from blood, prevented their full clinical utilization.

In recent years, $\mathrm{pH}$-responsive CPPs have been developed for targeted delivery based on the pH gradient between the tumor tissues and physiological environment (Lee, Gao \& Bae,2008; Shi et al., 2015; Jiang et al., 2012; Fei et al., 2014). Due to excess lactic acid secreted by solid tumors, the tumor extracellular environment shows a lower $\mathrm{pH}$ in comparison to normal physiological conditions (Tannock \& Rotin, 1989; Jähde, Rajewsky \& Baumgärtl, 1982; Cardone, Casavola \& Reshkin, 2005). The acidic tumor microenvironment mandates the development of $\mathrm{pH}$ responsive CPPs for improved selectivity of anti-cancer drugs (Liang et al.,2014; Han et al., 2015). The initial electrostatic interaction between anionic cellular membrane surfaces and cationic CPPs is believed to play a major role in their cellular uptake ( Ziegler, 2008; Guo, Peng \& Kang, 2016; Futaki et al., 2007).Thus, modulating this electrostatic interaction by masking or restoring the positive charge can significantly enhance the specificity of CPPs. Histidine, a unique amino acid, has no charge under physiological conditions, whereas it becomes protonated in acidic tumor microenvironments and exhibits $\mathrm{pH}$-dependent cellular uptake with a high 
affinity for cell membranes (Zaro, Fei\&Shen, 2012). A novel acid-activated CPP, TH, was designed and synthesized by our group by replacing all lysine residues of TK (AGYLLGKINLKKLAKL(Aib)KKIL-NH2) with histidine residues, which exhibited the desired features. At the same time, the toxicity of $\mathrm{TH}$ decreased under both in vitro and in vivo conditions compared to TK (Zhang et al., 2011).

However, due to the imidazole on histidine with a pKa around 6.5 , histidine could protonate into a net positive charge at pH values below 6.5(Zaro, Fei\&Shen, 2012; Ouahab et al., 2014), thereby activating the membrane penetrating activity of TH and allowing its entry into the cells. However, histidine becomes relatively insensitive to the tumor extracellular environment when the $\mathrm{pH}$ is in the6.5-7.2 range, thereby reducing the $\mathrm{pH}$-dependent penetrating activity of $\mathrm{TH}$. In order to extend the applications of acid-activated CPPs, it is necessary to improve their $\mathrm{pH}$ response. The ability of the imidazole group to accept protons is a key factor for protonation. Electron donating groups could render the $\mathrm{N}$ atom on the imidazole ring more alkaline and contribute to its ability to receive a proton, consequently facilitating the increase in pKa value.

In order to facilitate easier protonation of acid-activated CPPs and render them more sensitive to a weakly acidic environment, we introduced alkylated histidine analogues to acidactivated TH, for a more sensitive, acid-targeted drug delivery. Electron donating groups (methyl, ethyl, isopropyl, and butyl)were introduced to the imidazole group of L-histidineto construct a series of histidine analogs, L-histidine(methyl), L-histidine(ethyl), L-histidine(isopropyl) and Lhistidine(butyl). These histidine analogs were further introduced to $\mathrm{TH}$, forming methyl-TH, ethyl-TH, isopropyl-TH, and butyl-TH analogs. The $\mathrm{pH}$-dependent cellular uptake efficiencies of the new TH analogs were evaluated by flow cytometry and confocal laser scanning microscopy (CLSM), respectively. Importantly, the toxicities of these new TH analogs were examined. The antitumor drug CPT was conjugated to the new $\mathrm{TH}$ analogs, and its $\mathrm{pH}$-dependent cytotoxicity to cancer cells was compared. In short, this work explores a new avenue for development of improved, acid-activated CPPs as potential anticancer drug vectors for efficient targeted drug delivery. 


\section{Materials and methods}

101

102

103

104

105

106

107

108

109

110

111

112

113

114

115

116

117

118

119

120

121

122

123

124

\subsection{Materials}

Rink amide MBHA resin, protected amino acids, and other reagents and solvents for peptide synthesis were purchased from GL Biochem Ltd (Shanghai, China). Trifluoromethanesulfonic anhydride was purchased from Energy Chemical (Shanghai, China). Trifluoroacetic acid (TFA), DMF, piperidine, methanol and dichloromethane were of analytical grade and distilled before use. All other reagents and solvents were obtained from Tianjin Reagent Chemical Co. 3-(4,5-Dimethylthiazol-2-yl)-2,5-diphenyltetrazolium bromide (MTT) was purchased from Sigma-Aldrich (St. Louis, MO, USA), while fluorescein isothiocyanate (FITC) was purchased from Aladdin Reagent Co. Ltd. (Shanghai, China). LDH Cytotoxicity Assay Kit was purchased from Promega Co. Ltd. (Beijing, China).

2.2 Synthesis of Histidine Analogs

\section{Synthesis of L-his(R)-carbomethoxy}

\section{(1)L-his(methyl)-carbomethoxy trifluoromethanesulfonic anhydridem $(0.632 \mathrm{ml}$,} $3.75 \mathrm{mmol}$ )was dissolved in anhydrous dichloromethane $(10 \mathrm{ml})$, and stirred under argon atmosphere for $30 \mathrm{~min}$ at $-75^{\circ} \mathrm{C}$. Following, methanol $(3.75 \mathrm{mmol})$ and DIEA( $(0.65 \mathrm{ml}, 3.75 \mathrm{mmol})$ in anhydrous dichloromethane $(10 \mathrm{ml})$ were added dropwise into the solution. The solution was stirred for $30 \mathrm{~min}$ at $-75^{\circ} \mathrm{C}$, followed by the addition of L-histidine methyl ester( $\left.2.5 \mathrm{mmol}\right)$ in anhydrous dichloromethane $(10 \mathrm{ml})$ to the reaction flask. The mixture was then allowed to gradually warm to room temperature with overnight stirring (Qian, Liu \& Burke, 2011). After confirming the formation of L-histidine-carbomethoxy by thin layer chromatography, the solution was washed with saturated sodium bicarbonate solution twice, and saturated sodium chloride solution two more times. Solvents were removed by rotary evaporation to obtain dried $\left(\mathrm{Na}_{2} \mathrm{SO}_{4}\right)$. The oily solid $(5 \mathrm{mmol})$ was dissolved in dichloromethane. Following, trifluoroacetic acid $(3.888 \mathrm{ml}, 50 \mathrm{mmol})$ and triisopropylsilane $(1.1 \mathrm{ml}, 5.5 \mathrm{mmol})$ were added into the round- 
125 bottom flask containing the solid, and stirred for $4 \mathrm{~h}$ at room temperature. The mixture was 126 concentrated to a gum and purified by silica gel flash chromatography $\left(\mathrm{CH}_{2} \mathrm{Cl}_{2}: \mathrm{MeOH}\right.$, from $12740: 1$ to $10: 1$ ), with a yield of $80 \%$.

128

129

130

131

132

133

134

135

136

137

138

139

140

141

142

143

144

145 146

147

148

(2)L-his(ethyl)-carbomethoxy trifluoromethanesulfonic anhydride $(0.632 \mathrm{ml}, 3.75 \mathrm{mmol})$ was dissolved in anhydrous dichloromethane $(10 \mathrm{ml})$, and stirred under argon atmosphere for 30 min at $-75^{\circ} \mathrm{C}$. Following, ethanol $(3.75 \mathrm{mmol})$ and DIEA $(0.65 \mathrm{ml}, 3.75 \mathrm{mmol})$ were dissolved in anhydrous dichloromethane $(10 \mathrm{ml})$ and added dropwise to the solution. After stirring for $30 \mathrm{~min}$ at $-75^{\circ} \mathrm{C}$, L-histidine methyl ester $(2.5 \mathrm{mmol})$ was dissolved in anhydrous dichloromethane $(10$ $\mathrm{ml}$ ) and added to the reaction flask. After stirring for $3 \mathrm{~h}$ at $-75^{\circ} \mathrm{C}$, the temperature was raised to $40^{\circ} \mathrm{C}$ and stirred overnight, followed by stirring at room temperature for $8 \mathrm{~h}$. The formation of Lhistidine-carbomethoxy was confirmed by thin layer chromatography, after which the solution was washed with saturated sodium bicarbonate twice, and saturated sodium chloride two more times. Solvents were removed by rotary evaporation to provide dried $\left(\mathrm{Na}_{2} \mathrm{SO}_{4}\right)$ mixture as a gel. The oily solid ( $5 \mathrm{mmol}$ ) was dissolved in dichloromethane; following, trifluoroacetic acid (3.888 $\mathrm{ml}, 50 \mathrm{mmol})$ and triisopropylsilane $(1.1 \mathrm{ml}, 5.5 \mathrm{mmol})$ were added into the round-bottom flask containing the solid, and stirred for $4 \mathrm{~h}$ at room temperature. The mixture was concentrated to a gum and purified by silica gel flash chromatography $\left(\mathrm{CH}_{2} \mathrm{Cl}_{2}: \mathrm{MeOH}\right.$, from 40:1 to 10:1), with a yield of $70 \%$.

(3)L-his(isopropyl)-carbomethoxy trifluoromethanesulfonic anhydride $(0.632 \mathrm{ml}, 3.75 \mathrm{mmol})$ was dissolved in anhydrous dichloromethane $(10 \mathrm{ml})$, and stirred under argon atmosphere for 30 min at $-75^{\circ} \mathrm{C}$. Following, isopropanol $(3.75 \mathrm{mmol})$ was dissolved in anhydrous dichloromethane $(10 \mathrm{ml})$ with DIEA $(0.65 \mathrm{ml}, 3.75 \mathrm{mmol})$ and added dropwise to the solution. After stirring for $30 \min$ at $-75^{\circ} \mathrm{C}$, L-histidine methyl ester $(2.5 \mathrm{mmol})$ was dissolved in anhydrous dichloromethane $(10 \mathrm{ml})$ and added to the reaction flask and stirred for $4 \mathrm{~h}$ at $-75^{\circ} \mathrm{C}$. Following, 
149 the temperature was raised to $-40^{\circ} \mathrm{C}$ and the solution was stirred for $3 \mathrm{~h}$. Finally, the mixture was

150 allowed to gradually warm to room temperature with overnight stirring. The formation of L151 histidine-carbomethoxy was confirmed by thin layer chromatography, after which the solution 152 was washed with saturated sodium bicarbonate solution twice, and saturated sodium chloride 153 solution two more times. Solvents were removed by rotary evaporation to provide dried $\left(\mathrm{Na}_{2} \mathrm{SO}_{4}\right)$ 154 mixture as a gel. The oily solid $(5 \mathrm{mmol})$ was dissolved in dichloromethane. Following, 155 trifluoroacetic acid $(3.888 \mathrm{ml}, 50 \mathrm{mmol})$ and triisopropylsilane $(1.1 \mathrm{ml}, 5.5 \mathrm{mmol})$ were added 156 into the round-bottom flask containing the solid, and stirred for $4 \mathrm{~h}$ at room temperature. The 157 mixture was concentrated to a gum and purified by silica gel flash chromatography $158\left(\mathrm{CH}_{2} \mathrm{Cl}_{2}: \mathrm{MeOH}\right.$, from $90: 1$ to $\left.40: 1\right)$, with a yield of $38.7 \%$.

(4)L-his(butyl)-carbomethoxy trifluoromethanesulfonic anhydride (0.632 $\mathrm{ml}, 3.75 \mathrm{mmol})$ was dissolved in anhydrous dichloromethane $(10 \mathrm{ml})$, and stirred under argon atmosphere for $30 \mathrm{~min}$ at $-75^{\circ} \mathrm{C}$. Following, butanol $(3.75 \mathrm{mmol})$ was dissolved in anhydrous dichloromethane $(10 \mathrm{ml})$ with DIEA $(0.65 \mathrm{ml}, 3.75 \mathrm{mmol})$ and added dropwise to the solution. After stirring for $30 \mathrm{~min}$ at $-75^{\circ} \mathrm{C}$, L-histidine methyl ester $(2.5 \mathrm{mmol})$ was dissolved in anhydrous dichloromethane (10ml) and added to the reaction flask, with stirring for $4 \mathrm{~h}$ at $-75^{\circ} \mathrm{C}$. Following, the temperature was raised to $-40^{\circ} \mathrm{C}$ and the mixture was stirred for $3 \mathrm{~h}$, after which it was allowed to gradually warm to room temperature with overnight stirring. After the formation of of L-histidine-carbomethoxy was confirmed by thin layer chromatography, the solution was washed with saturated sodium bicarbonate solution twice, followed by saturated sodium chloride solution for two more times. Solvents were removed by rotary evaporation to provide dried $\left(\mathrm{Na}_{2} \mathrm{SO}_{4}\right)$ mixture as a gel. The oily solid (5 mmol) was dissolved in dichloromethane. Following, trifluoroacetic acid (3.888 ml, $50 \mathrm{mmol})$ and triisopropylsilane $(1.1 \mathrm{ml}, 5.5 \mathrm{mmol})$ were added to the round-bottom flask containing the solid, and stirred for $4 \mathrm{~h}$ at room temperature. The mixture were concentrated to a gum and purified by silica gel flash chromatography $\left(\mathrm{CH}_{2} \mathrm{Cl}_{2}: \mathrm{MeOH}\right.$, from $80: 1$ to $\left.40: 1\right)$, with a 
174

175

176

yield of $36.4 \%$

\subsubsection{Synthesis of L-histidine-carbomethoxy}

Fmoc-histidine(Trt)-OH (3.1 g, $5 \mathrm{mmol})$ was dissolved in anhydrous after which thionyl chloride $(1.49 \mathrm{ml}, 20 \mathrm{mmol})$ was added dropwise to the solution with stirring in an ice bath. Following, the solution was stirred for $2 \mathrm{~h}$ at room temperature. After thin layer chromatography confirmed the disappearance of histidine, solvents were removed by rotary evaporation. White precipitate was dissolved in dichloromethane and washed with a saturated solution of sodium carbonate twice. Solvents were removed by rotary evaporation to provide dried $\left(\mathrm{Na}_{2} \mathrm{SO}_{4}\right)$, at $92 \%$ yield.

\subsubsection{Synthesis of L-his(R)-carbomethoxy}

Trifluoromethanesulfonicanhydride $(0.632 \mathrm{ml}, 3.75 \mathrm{mmol})$ was dissolved in anhydrous dichloromethane $(10 \mathrm{ml})$, and stirred under argon atmosphere at $-75^{\circ} \mathrm{C}$ for $30 \mathrm{~min}$. Following, alcohols (such as ethanol, isopropanol, butanol, $3.75 \mathrm{mmol})$ and $\operatorname{DIEA}(0.65 \mathrm{ml}, 3.75 \mathrm{mmol})$ were dissolved in anhydrous dichloromethane $(10 \mathrm{ml})$ and added dropwise to the solution. After stirring for $30 \mathrm{~min}$ at $-75^{\circ} \mathrm{C}$, L-histidine methyl ester $(2.5 \mathrm{mmol})$ was dissolved in anhydrous dichloromethane $(10 \mathrm{ml})$ and added to the reaction flask, with stirring for $4 \mathrm{~h}$ at $-75^{\circ} \mathrm{C}$. The mixture was then allowed to gradually warm to room temperature with overnight stirring (Qian, Liu \& Burke, 2011). The formation of L-histidine-carbomethoxy was confirmed by thin layer chromatography, and the solution was washed with saturated sodium bicarbonate twice, and saturated sodium chloride solution for two more times. Solvents were removed by rotary evaporation to provide dried $\left(\mathrm{Na}_{2} \mathrm{SO}_{4}\right)$ mixture as a gel. The oily solid $(5 \mathrm{mmol})$ was dissolved in dichloromethane. Following, trifluoroacetic acid $(3.888 \mathrm{ml}, 50 \mathrm{mmol})$ and triisopropylsilane $(1.1 \mathrm{ml}$, $5.5 \mathrm{mmol})$ were added into the round-bottom flask containing the solid, and stirred for $4 \mathrm{~h}$ at room temperature. The mixture was concentrated to a gum and purified by silica gel flash 
199

200

201

202

203

204

205

206

207

208

209

210

211

212

213

214

215

chromatography $\left(\mathrm{CH}_{2} \mathrm{Cl}_{2}: \mathrm{MeOH}\right.$, from $80: 1$ to $\left.40: 1\right)$, with a yield of $38.7 \%$.

\subsubsection{Synthesis of $\mathrm{L}-\mathrm{his}(\mathrm{R})$}

Compound 2 was dissolved in THF, and $4.8 \% \mathrm{LiOH} \cdot \mathrm{H}_{2} \mathrm{O}$ was added dropwise to the reaction flask in an ice bath and stirred for 5 min. Following, the solution was acidified to $\mathrm{pH} 5$ using aqueous $\mathrm{HCl}(1 \mathrm{mmol})$, after which ethyl acetate was added to the solution to extract four times. The organic layer was dried using anhydrous sodium sulfate concentrated in vacuo. Product 3 was obtained and the structure was detected by ${ }^{1} \mathrm{H}-\mathrm{NMR}\left(300 \mathrm{MHz}, \mathrm{CDCl}_{3}\right)$.

\subsection{Synthesis of TH analog peptides}

\subsection{Synthesis of TH analog peptides}

All peptides shown in Table1 were synthesized on a MBHA $(0.43 \mathrm{mmol} / \mathrm{g})$ resin using the standard Fmoc-chemistry-based strategy. Fluorescein moiety (FITC) was attached to the Nterminusvia an aminohexanoic acid spacer by treating the resin-bound peptide $(0.1 \mathrm{mmol})$ with FITC $(0.1 \mathrm{mmol})$ and diisopropyl ethyl amine $(0.5 \mathrm{mmol})$ in DMF for $12 \mathrm{~h}$. All crude peptides were purified and analyzed by reversed-phase high performance liquid chromatography (RPHPLC) on a C18 column, and then characterized by electrospray ionization mass spectrometry (ESI-MS).

\begin{tabular}{|c|c|c|c|c|}
\hline \multirow[t]{2}{*}{ Peptides } & \multirow[t]{2}{*}{ Amino acid sequences } & \multicolumn{2}{|c|}{ Molecular mass } & \multirow{2}{*}{$\begin{array}{l}\text { RP-HPLC retention } \\
\text { times }(\mathrm{min})^{\mathrm{b}}\end{array}$} \\
\hline & & Calculated & Measured $^{\mathrm{a}}$ & \\
\hline \multirow[t]{2}{*}{$\mathrm{TH}$} & AGYLLGHINLHHLAHL(Ai & 2365 & 2365.39 & 18.539 \\
\hline & b)HHIL-NH ${ }_{2}$ & & & \\
\hline Methyl-TH & AGYLLGH $_{M} I_{N L H} H_{M} L A H$ & 2448 & 2448.44 & 18.058 \\
\hline
\end{tabular}




\begin{tabular}{|c|c|c|c|c|}
\hline & ${ }_{\mathrm{M}} \mathrm{L}(\mathrm{Aib}) \mathrm{H}_{\mathrm{M}} \mathrm{H}_{\mathrm{M}} \mathrm{IL}-\mathrm{NH}_{2}$ & & & \\
\hline Ethyl-TH & $\begin{array}{l}\text { AGYLLGH }_{\mathrm{E}} \mathrm{INLH}_{\mathrm{E}} \mathrm{H}_{\mathrm{E}} \mathrm{LAH}_{\mathrm{E}} \\
\mathrm{L}(\mathrm{Aib}) \mathrm{H}_{\mathrm{E}} \mathrm{H}_{\mathrm{E}} \mathrm{IL}-\mathrm{NH}_{2}\end{array}$ & 2532 & 2532.53 & 18.623 \\
\hline Isopropyl-TH & $\begin{array}{l}\text { AGYLLGH }_{\mathrm{I}} \mathrm{NLH}_{\mathrm{I}} \mathrm{H}_{\mathrm{I}} \mathrm{LAH}_{\mathrm{I}} \mathrm{L}( \\
\text { Aib) } \mathrm{H}_{\mathrm{I}} \mathrm{H}_{\mathrm{I}} \mathrm{IL}-\mathrm{NH}_{2}\end{array}$ & 2616 & 2616.63 & 19.041 \\
\hline Butyl-TH & $\begin{array}{l}\text { AGYLLGH }_{B} \mathrm{INLH}_{\mathrm{B}} \mathrm{H}_{\mathrm{B}} \mathrm{LAH}_{\mathrm{B}} \\
\mathrm{L}(\mathrm{Aib}) \mathrm{H}_{\mathrm{B}} \mathrm{H}_{\mathrm{B}} \mathrm{IL}-\mathrm{NH}_{2}\end{array}$ & 2700 & 2700.74 & 20.561 \\
\hline
\end{tabular}

${ }^{a}$ Molecular masses were determined by electrospray ionization mass spectrometry.

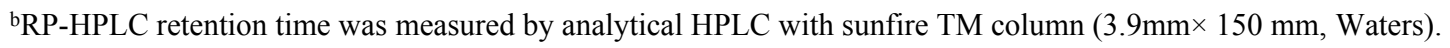

$\mathrm{H}_{\mathrm{M}}$ : L-his(Methyl); $\mathrm{H}_{\mathrm{E}}$ : L-his(Ethyl); $\mathrm{H}_{\mathrm{I}}$ : L-his(Isopropyl); $\mathrm{H}_{\mathrm{B}}$ : L-his(Butyl)

All peptides were synthesized with cysteine on the N-terminus, with the thiol group serving as the attachment site for the cleavable linker. Following a procedure reported in previous literature (Henne, Doorneweerd\&Hilgenbrink, 2006), CPT was attached to the cysteine of peptides with a disulfide carbonate releasable linker.

\subsection{Cell culture}

Hela cells used in this study were obtained from Laboratory Center for Medical Science of Lanzhou University. Cells were maintained in RPMI1640 medium (Gibco BRL,Gaithersburg, MD, USA) containing 10\% heat-inactivated neonatalbovine serum (NBS) (Sijiqing Biotech, Hangzhou, China), penicillin $(100 \mathrm{IU} / \mathrm{mL})$ and streptomycin $(100 \mu \mathrm{g} / \mathrm{mL})$. All cell lines were cultured in a $5 \% \mathrm{CO}_{2}$ humidifiedatmosphere at $37^{\circ} \mathrm{C}$.

\subsection{In vitro cellular uptake study}


232

233

234

235

236

237

238

239

240

241

242

243

244

245

246

247

248

249

250

251

252

253

254

255

256

\subsubsection{Quantitative cellular uptake assay}

To access whether $\mathrm{TH}$ analogs exhibited better $\mathrm{pH}$-sensitivity than $\mathrm{TH}$, HeLa cells $\left(1 \times 10^{5} \mathrm{cells} /\right.$ well $)$ were plated into 24 well microplates and cultured for $24 \mathrm{~h}$. After one hour long incubation with serum-free medium containing $5 \mu \mathrm{M}$ FITC- labeled peptides and adjusted to $\mathrm{pH}$ $7.4,6.5$ or 6.0 , the cells were washed twice with PBS and then incubated with $0.02 \%$ trypsin for one min. The cells were harvested and centrifuged at $1000 \mathrm{rpm}$ for $5 \mathrm{~min}$. Subsequently, the cell pellet was suspended and washed twice with PBS and resuspended in PBS. Finally, fluorescence intensity of 10,000 cells was analyzed with an FACS caliber flow cytometer using 488-nm laser excitation.

\subsubsection{Confocal laser scanning microscopy}

To obtain a direct insight into the distribution of FITC-labeled peptides in cells, HeLa cells $\left(6 \times 10^{4}\right.$ cells/well $)$ were plated in a glass-bottom culture dish for $24 \mathrm{~h}$ and then incubated with the FITC-labeled peptides using conditions and concentrations described above. After $1 \mathrm{~h}$ incubation at $37{ }^{\circ} \mathrm{C}$, the cells were washed with cold PBS three times and imaged using confocal laser scanning microscopy.

\subsection{In vitro cytotoxicity assays}

\subsubsection{MTT assay}

Cytotoxicity of all peptides against HeLa cells was evaluated using the MTT assay under varying $\mathrm{pH}$ conditions $\left(\mathrm{pH} \mathrm{7.4,6.5}\right.$ and 6.0). Cells were seeded at $1 \times 10^{4}$ cells/well in 96-well plates, $24 \mathrm{~h}$ before treatment. After washing, cells were treated with serum-free medium, adjusted to $\mathrm{pH} 7.4,6.5$ or 6.0 , and containing various concentrations of peptides. After $2 \mathrm{~h}$ incubation, $10 \mu \mathrm{L}$ of MTT $(5 \mathrm{mg} / \mathrm{mL})$ was added to each well and incubated for another $4 \mathrm{~h}$ at 37 ${ }^{\circ} \mathrm{C}$. Following, the medium was removed and cells were dissolved by $150 \mu \mathrm{L}$ dimethyl sulfoxide. Absorbance was determined using a microplate reader at $490 \mathrm{~nm}$. Cell viability (\%) was calculated using the following equation: $A_{\text {test }} / A_{\text {control }} \times 100 \%$, where $A_{\text {test }}$ and $A_{\text {control }}$ represent 
257 the absorbance of cells treated with different test solutions and blank culture media, respectively.

258

259

260

261

262

263

264

265

266

267

268

269

270

271

272

273

274

275

276

277

278

279

280

281

2.7.2 Lactate dehydrogenase (LDH) leakage assay

Membrane integrity was evaluated using the CytoTox-ONE assay. Cells were seeded at $1 \times$ $10^{4}$ cells/well in a 96-well plate $24 \mathrm{~h}$ before treatment. After $2 \mathrm{~h}$ incubation with $100 \mu \mathrm{L}$ serumfree medium, adjusted to $\mathrm{pH} 7.4,6.5$ or 6.0 and containing various concentrations of peptides, 40 $\mu \mathrm{L}$ of medium was transferred to a black fluorescence plate and incubated for 10 min with $40 \mu \mathrm{L}$ of CytoTox-ONE reagent, followed by $20 \mu \mathrm{L}$ of stop solution. Fluorescence was recorded with an excitation wavelength of $560 \mathrm{~nm}$ and emission wavelength of $590 \mathrm{~nm}$. Untreated cells were defined as those where no leakage was observed while $100 \%$ leakage was defined as a total release of $\mathrm{LDH}$ due to cell lysis in $0.2 \%$ Triton $\mathrm{X}-100$.

\subsection{Hemolysis assays}

To evaluate the safety of the peptide for application, hemolysis assays were performed. Fresh mouse blood was collected in heparin sodium-containing centrifuge tubes. Erythrocytes were separated by centrifugation at $800 \times \mathrm{g}$ for $10 \mathrm{~min}$ and washed three times with phosphate buffered saline (PBS). Obtained erythrocytes were resuspended in PBS to $8 \%(\mathrm{v} / \mathrm{v})$. $100 \mu \mathrm{L}$ of the peptide solution of various concentrations and $100 \mu \mathrm{L}$ of the erythrocyte suspension were added to the wells of a 96-well plate. PBS and 0.2\% TritonX-100 were used as agents for $0 \%$ and $100 \%$ hemolysis, respectively. Plates were incubated for $1 \mathrm{~h}$ at $37^{\circ} \mathrm{C}$ and centrifuged at $1200 \times \mathrm{g}$ for $15 \mathrm{~min} .100 \mu \mathrm{L}$ of each supernatant was transferred to a 96-well plate, and the release of hemoglobin was determined using a microplate reader at $490 \mathrm{~nm}$.

\subsection{In vitro antitumor efficacy}

The antiproliferative effects of all conjugates were determined by the MTT assay. Cells were seeded in 96-well plates at a density of $5 \times 10^{3}$ cells/well. After $30 \mathrm{~min}$ incubation with serum-free medium adjusted to $\mathrm{pH} 7.4,6.5$ or 6.0 and containing various concentrations of agents, the remaining agents that did not enter the cells were washed to remove the old medium. 
282 After $72 \mathrm{~h}$, the cytotoxicity of relevant agents was determined by the MTT assay as described 283 earlier.

\section{Results}

\subsection{Design and synthesis of acid-activated TH analogs} histidine. Following, electrophilic substitution reaction was used to introduce electron donating groups to the imidazole group of L-histidine. Finally, the Trt protective group was shucked off to give histidine analogs under acidic and basic conditions, respectively.

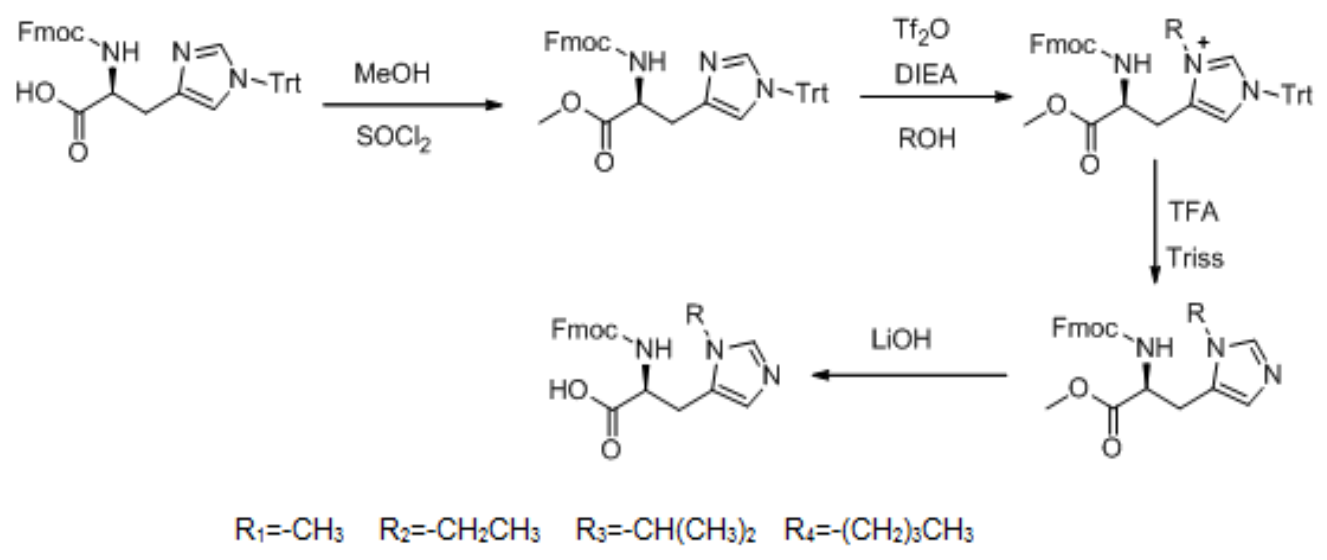


294 assigned to the corresponding protons, indicating successful synthesis.

A
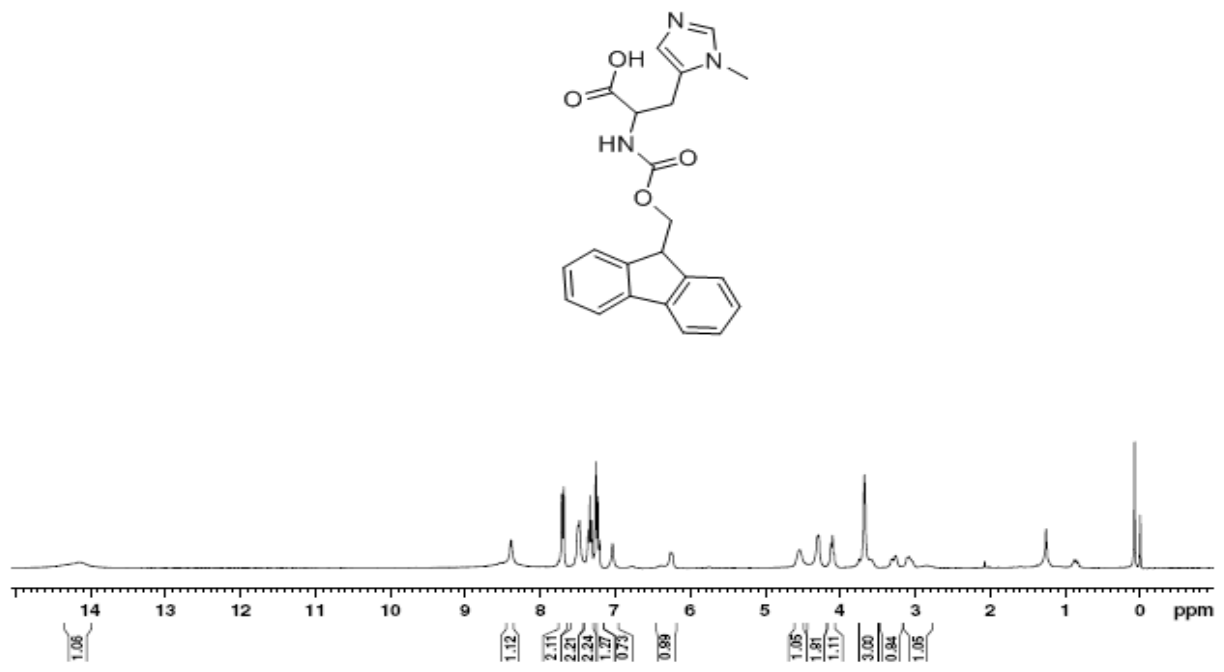
B
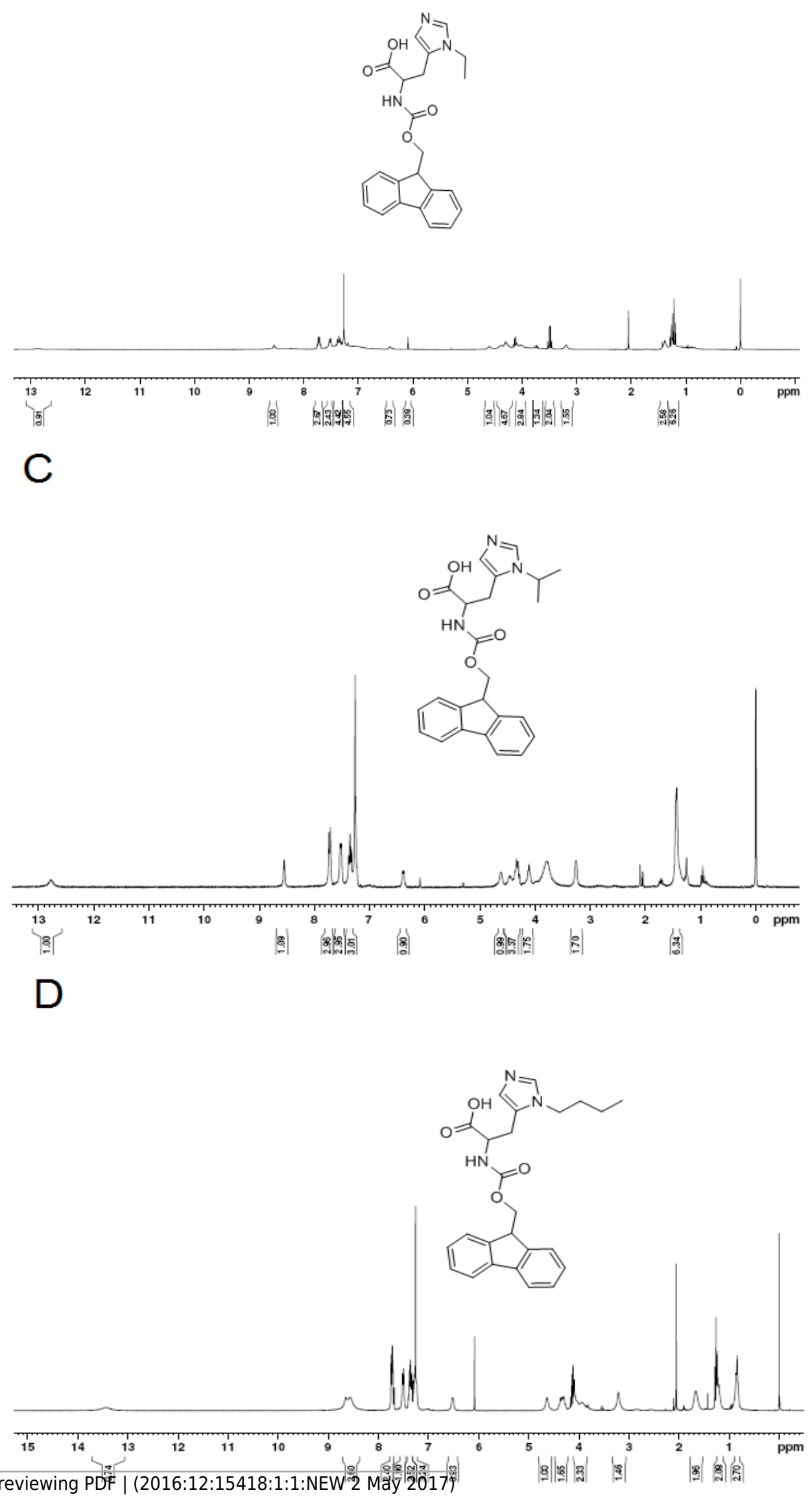
296

297

298

299

300

301

302

303

304

305

306

307

308

309

310

311

312

313

314

Fig.1. The ${ }^{1} \mathrm{H}$ NMR spectrum of L-histidine analogs in $\mathrm{CDCl}_{3}$. (A) ${ }^{1} \mathrm{H} \mathrm{NMR}\left(300 \mathrm{MHz}, \mathrm{CDCl}_{3}\right): \delta \quad=$ 14.13(s,1H),8.39(s,1H), 7.70(d,J=7.5Hz,2H),7.48(d,J=6.0Hz,2H), 7.34(t,J=7.2Hz,2H), 7.26-7.21(m,1H), 7.03(s, 1H),

6.25(d,J=6Hz,1H),4.54(s,1H),4.30-4.29(m,2H),4.12-4.10(m,1H),3.68(s,3H),3.30-3.26(m,1H),3.11-3.09(m,1H).

(B) ${ }^{1} \mathrm{H}$

$\mathrm{NMR}\left(300 \mathrm{MHz}, \quad \mathrm{CDCl}_{3}\right): \delta=\quad 12.88(\mathrm{~s}, 1 \mathrm{H}), \quad 8.54(\mathrm{~s}, 1 \mathrm{H}), \quad 7.72(\mathrm{~d}, \mathrm{~J}=6.6 \mathrm{Mz}, 3 \mathrm{H}), \quad 7.52(\mathrm{~d}, \mathrm{~J}=7.2 \mathrm{~Hz}, 3 \mathrm{H}), \quad 7.38(\mathrm{t}, \mathrm{J}=7.5 \mathrm{~Hz}, 3 \mathrm{H})$, 6.42(d,J=6.9Hz,1H), 4.59(s,1H), 4.43-4.29(m,2H), 4.04-4.0(m,1H), 3.5-3.4(m,2H), 3.19(s,2H), 1.43-1.38(m,3H). (C) $\quad{ }^{1} \mathrm{H}$ $\operatorname{NMR}\left(300 \mathrm{MHz}, \quad \mathrm{CDCl}_{3}\right): \quad \delta=12.77(\mathrm{~s}, 1 \mathrm{H}), \quad 8.55(\mathrm{~s}, 1 \mathrm{H}), \quad 7.72(\mathrm{~d}, \mathrm{~J}=7.5 \mathrm{~Hz}, 3 \mathrm{H}), \quad 7.52(\mathrm{~d}, \mathrm{~J}=6.3 \mathrm{~Hz}, 3 \mathrm{H}), \quad 7.35(\mathrm{t}, \mathrm{J}=7.2 \mathrm{~Hz}, 3 \mathrm{H})$, $6.39(\mathrm{~d}, \mathrm{~J}=5.7,1 \mathrm{H}), \quad 4.61(\mathrm{~s}, 1 \mathrm{H}), \quad 4.46-4.29(\mathrm{~m}, 3 \mathrm{H}), \quad 4.20-4.11(\mathrm{~m}, 1 \mathrm{H}), \quad 3.26(\mathrm{~s}, 2 \mathrm{H}), \quad 1.44(\mathrm{~s}, 6 \mathrm{H}) . \quad(\mathrm{D}) \quad{ }^{1} \mathrm{H} \quad \mathrm{NMR}(300 \mathrm{MHz}$, $\left.\mathrm{CDCl}_{3}\right): \delta=8.45(\mathrm{~s}, 1 \mathrm{H}), \quad$ 7.71(d,J=7.5Hz,2H), $\quad$ 7.52(d,J=7.2Hz,2H), $\quad$ 7.35(t,J=7.2Hz,2H),7.24$7.21(\mathrm{~m}, 3 \mathrm{H}), 6.42(\mathrm{~d}, \mathrm{~J}=5.7 \mathrm{~Hz}, 1 \mathrm{H}), 4.59(\mathrm{~s}, 1 \mathrm{H}), 4.35-4.29(\mathrm{~m}, 2 \mathrm{H}), 4.12-3.95(\mathrm{~m}, 3 \mathrm{H}), 3.20(\mathrm{~s}, 2 \mathrm{H}), 1.66-1.64(\mathrm{~m}, 2 \mathrm{H}), 1.23-$

$1.21(\mathrm{~m}, 2 \mathrm{H}), 0.86-0.82(\mathrm{~m}, 3 \mathrm{H})$

The histidine of TH was substituted by these histidine analogs, and formed the TH analogs: methyl-TH, ethyl-TH, isopropyl-TH, and butyl-TH, respectively. The TH analog peptides were synthesized manually by the standard Fmoc-chemistry-based strategy.

\subsection{Cellular uptake of TH analogs}

To determine the pH-response of these new analogs and the role of alkyl moiety at the C-2 position of histidine, the cellular uptake of FITC-labeled TH analogs in HeLa cells was quantified by flow cytometry at various $\mathrm{pH}$. As shown in Figure 2, fluorescence intensity of FITC-methyl-TH at pH 6.5 and 6.0 was comparable to that at $\mathrm{pH} 7.4$.

Interestingly, ethyl-TH exhibited lower fluorescence intensity than $\mathrm{TH}$ at $\mathrm{pH} 7.4$ and 6.5, while fluorescence intensity of ethyl-TH at $\mathrm{pH} 6.0$ increased substantially, to a quantitative level similar to that of $\mathrm{TH}$ at $\mathrm{pH}$ 6.0. It is shows that ethyl-TH increased its fluorescence intensity much greatly from $\mathrm{pH} 7.4$ and 6.5 to $\mathrm{pH} 6.0$ than $\mathrm{TH}$. This suggested that the $\mathrm{pH}$-responsive effect of ethyl-TH is better than that of TH at lower $\mathrm{pH}$ values."

Furthermore, the internalization ability of butyl-TH improved significantly when butylated histidine was introduced to the $\mathrm{TH}$ peptide. Fluorescence intensity of butyl-TH increased remarkably in comparison to that of $\mathrm{TH}$ at all $\mathrm{pH}$ values. However, butyl-TH presented approximately 1.72-fold higher fluorescence intensity than $\mathrm{TH}$ at $\mathrm{pH} 6.5$, as well as higher 
323

324

325

326

327

328

329

330

331

332

333

334

335
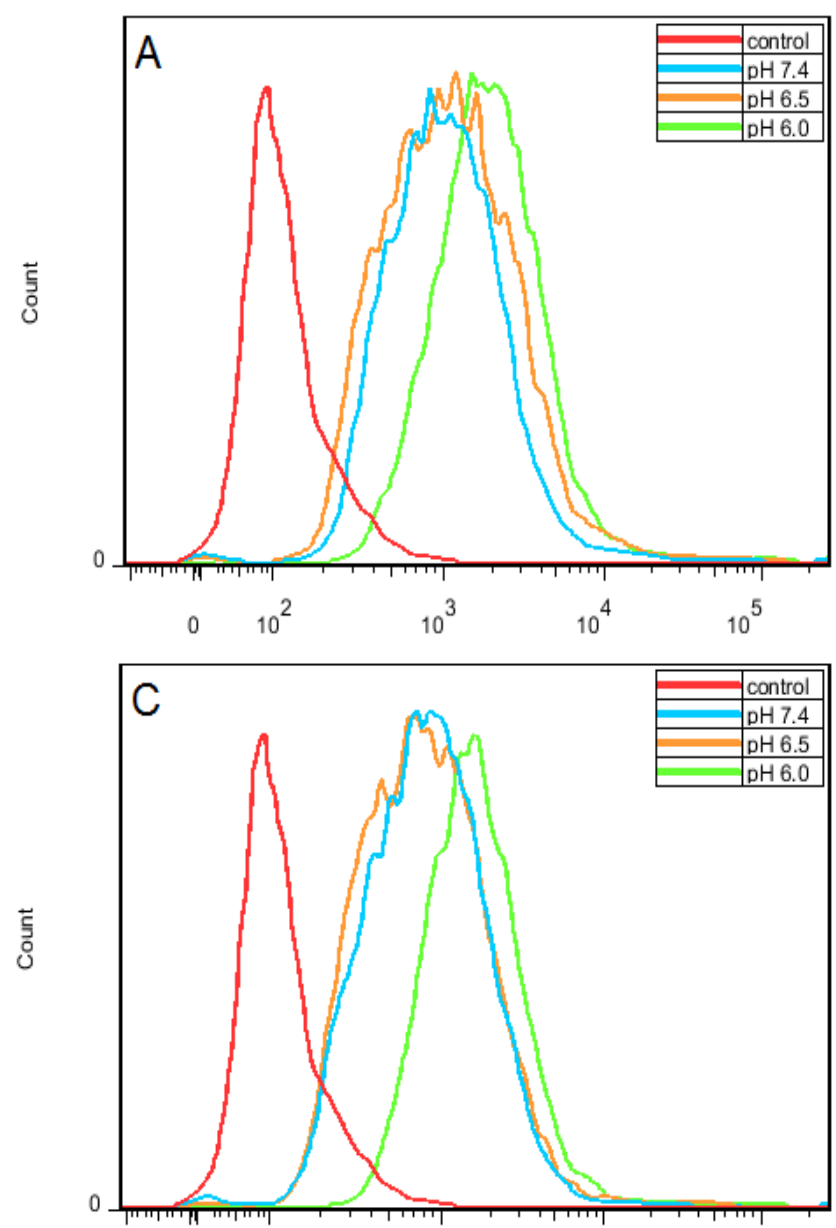

Peer] reverewing PDF $100(2016: 12: 154$ 18:1:1:NEWW 2 May 2017) FITC-A
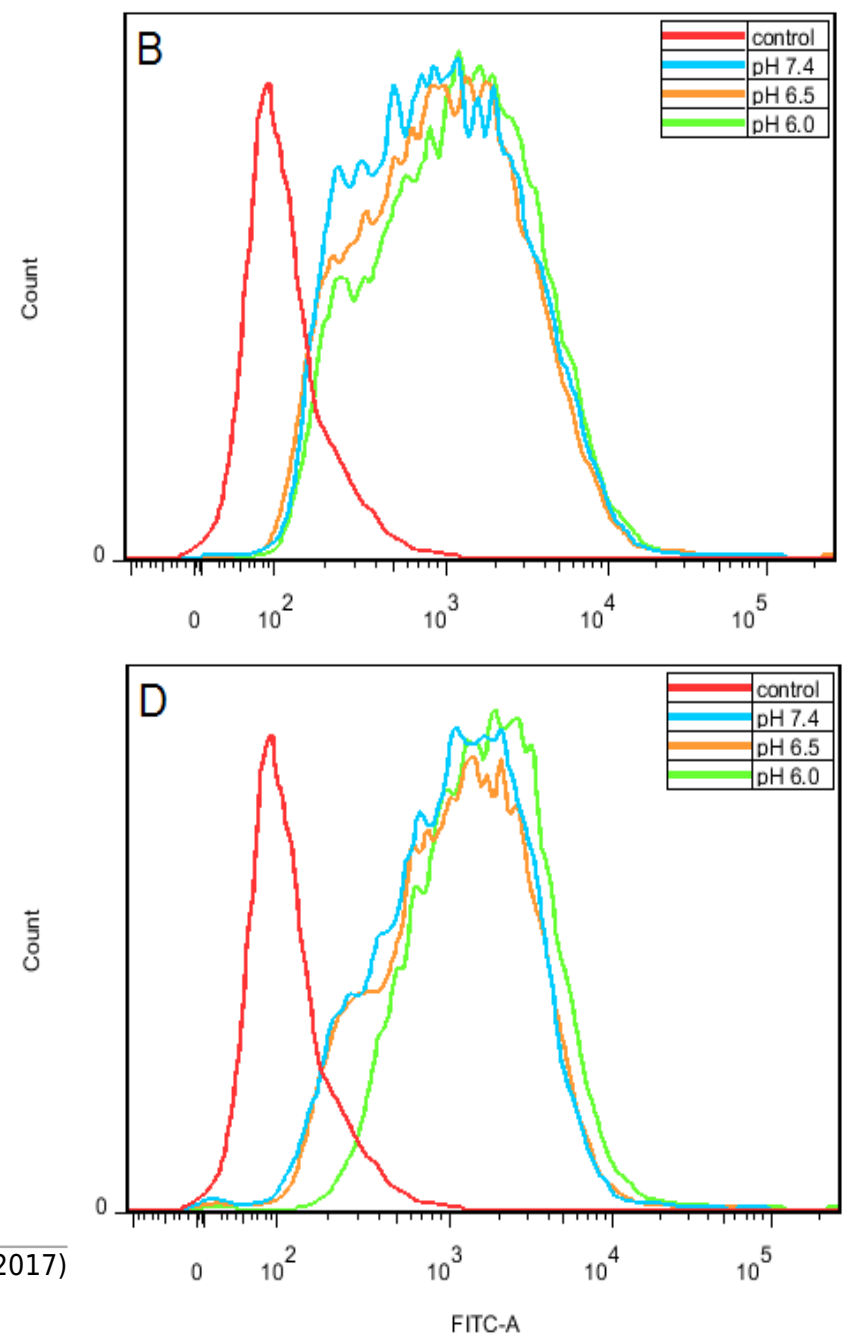

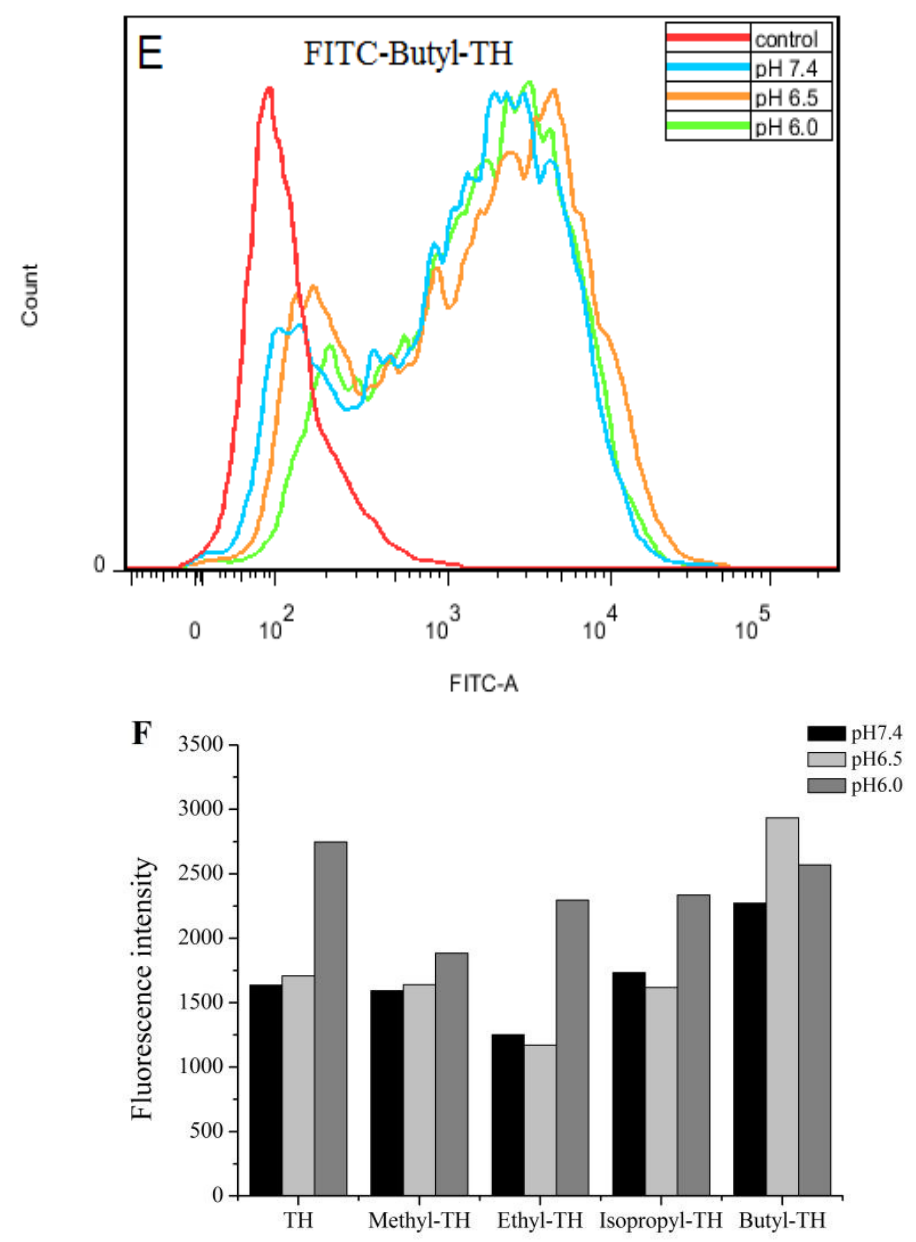

337 Fig.2. Flow cytometry analysis of Hela cells incubated with $5 \mu \mathrm{M}$ FITC labeled TH analogs at different $\mathrm{pH}$ conditions(pH7.4, 338 pH6.5 and pH6.0) for 1h. Hela cells incubated without FITC labeled TH analogues were used as control. (A) FITC-TH. (B) 339 FITC-Methyl-TH. (C) FITC-Ethyl-TH. (D) FITC-Isopropyl-TH. (E) FITC-Butyl-TH. (F) Fluorescence intensity of internalized

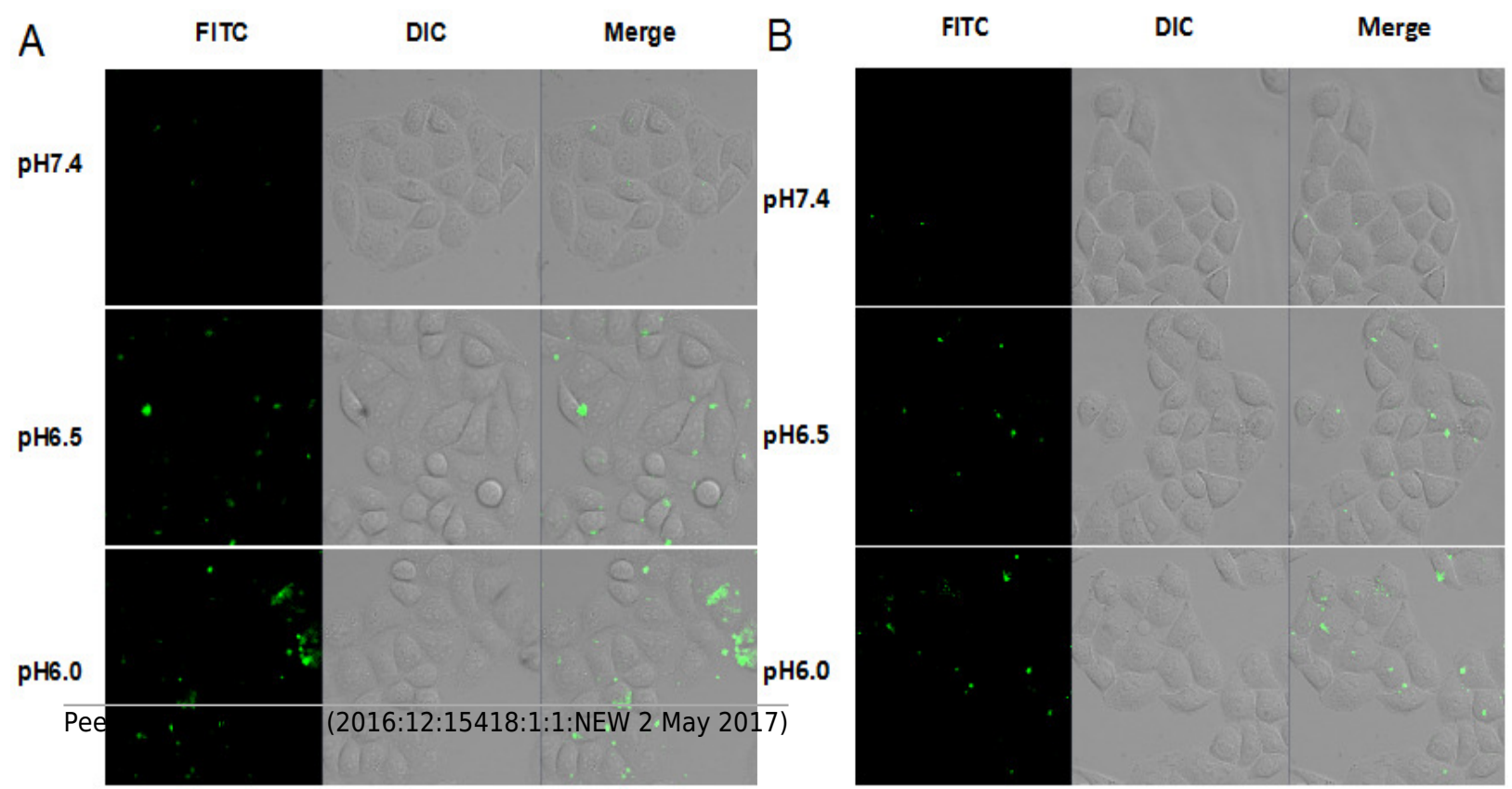


340 all peptides.
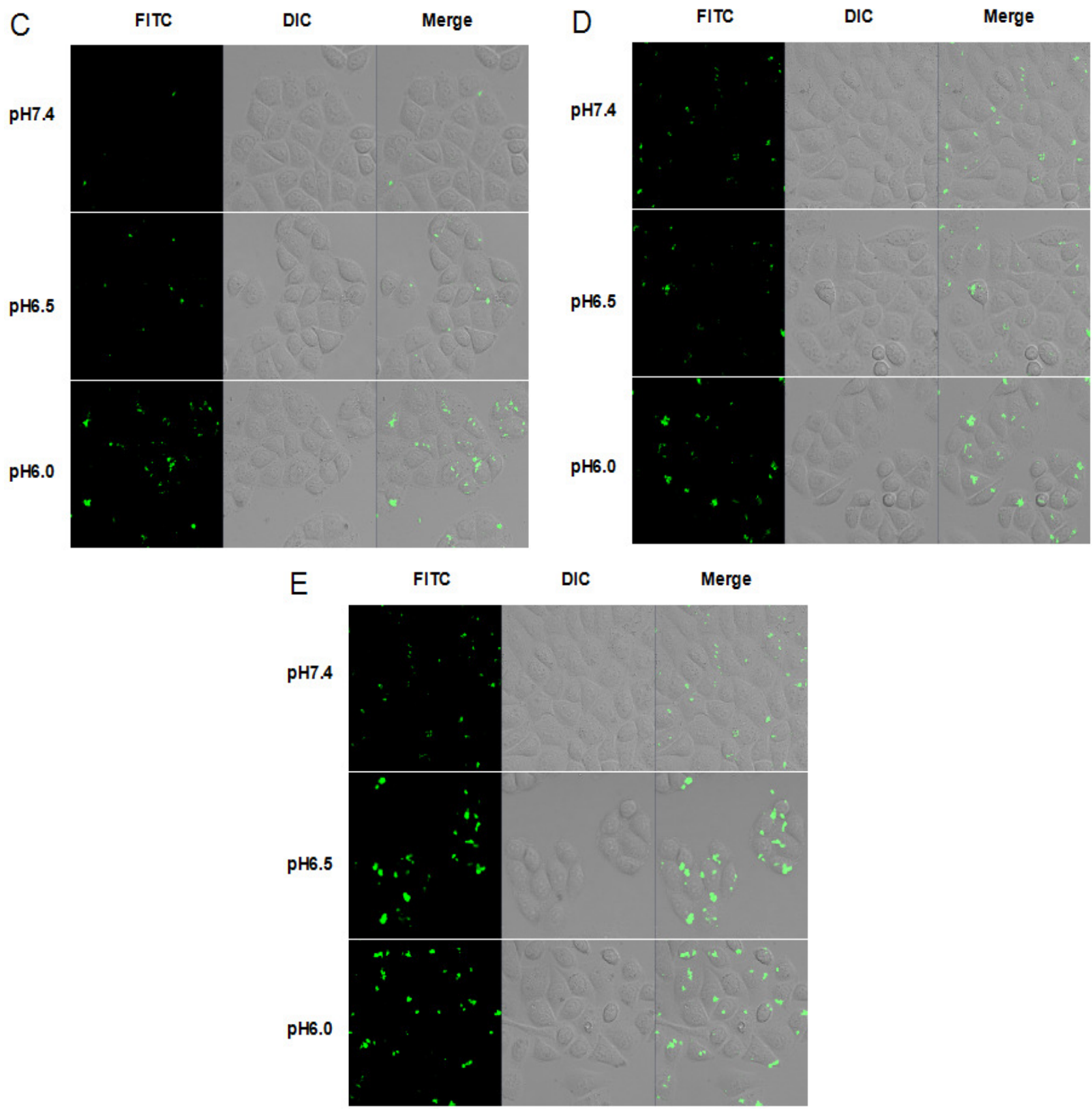

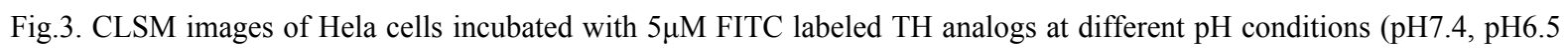


346

347

348

349

350

351

352

353

354

355

356

357

358

359

360

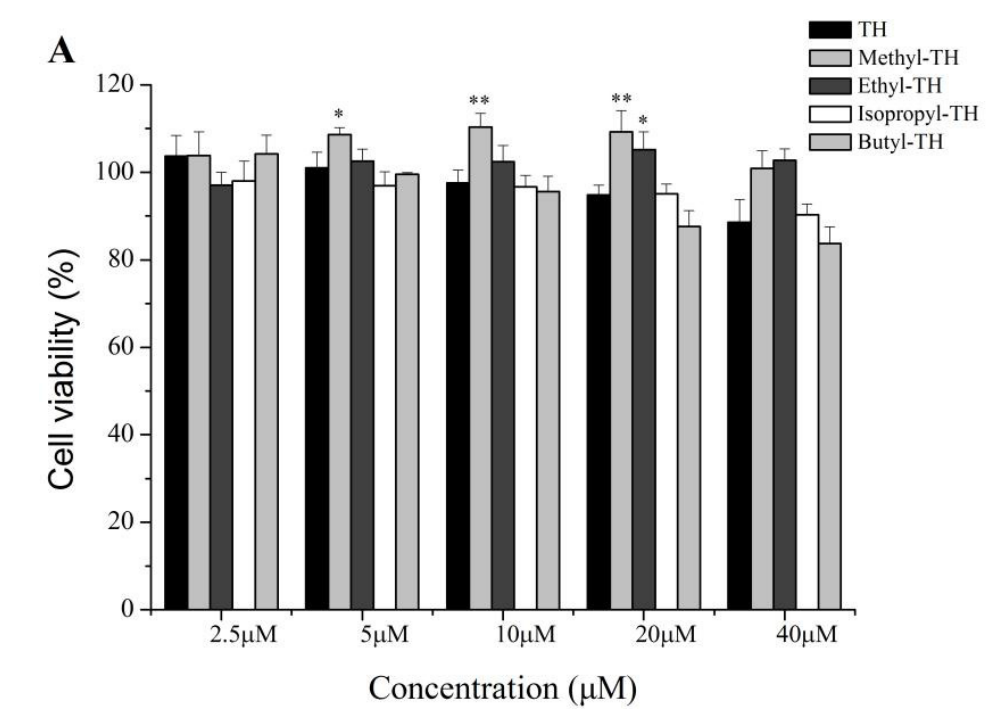

\subsection{In vitro cytotoxicity study} ethyl-TH, increased at the concentration of $20 \mu \mathrm{M}$.

The cytotoxicity of $\mathrm{TH}$ analogs at different $\mathrm{pH}$ was evaluated with the MTT assay. As shown in Figure 4A, none of the peptides have shown cytotoxicity against HeLa cells at pH7.4, with cell viability greater than $83 \%$ at the concentration of $20 \mu \mathrm{M}$. It is worth noting that methylTH didn't show any significant cytotoxicity compared to the other three $\mathrm{TH}$ analogs at low $\mathrm{pH}$ ( $\mathrm{pH} 6.5$ and $\mathrm{pH}$ 6.0); this can probably be attributed to a decreased cell-penetrating activity of methyl-TH after the introduction of a methyl moiety (Fig.2). This is consistent with a previous report (Song JJ et al, 2012) that found that TP10 analogs exhibited lower penetrating activity with less cytotoxicity. It has also been observed that isopropyl-TH and butyl-TH didn't show obvious cytotoxic variation from $\mathrm{pH} 7.4$ to $\mathrm{pH} 6.0$, indicating that the cytotoxicity of $\mathrm{TH}$ after modification with isopropyl and butyl did not increase proportionally with the increase in the length of alkylated groups. Curiously, the viability of cells treated with $\mathrm{TH}$ and ethyl-TH at different concentrations was higher than $80 \%$ at $\mathrm{pH} 7.4$ and $\mathrm{pH}$ 6.5, indicating no significant cytotoxicity. However, when the $\mathrm{pH}$ value reached 6.0, the cytotoxicity of $\mathrm{TH}$, and especially 

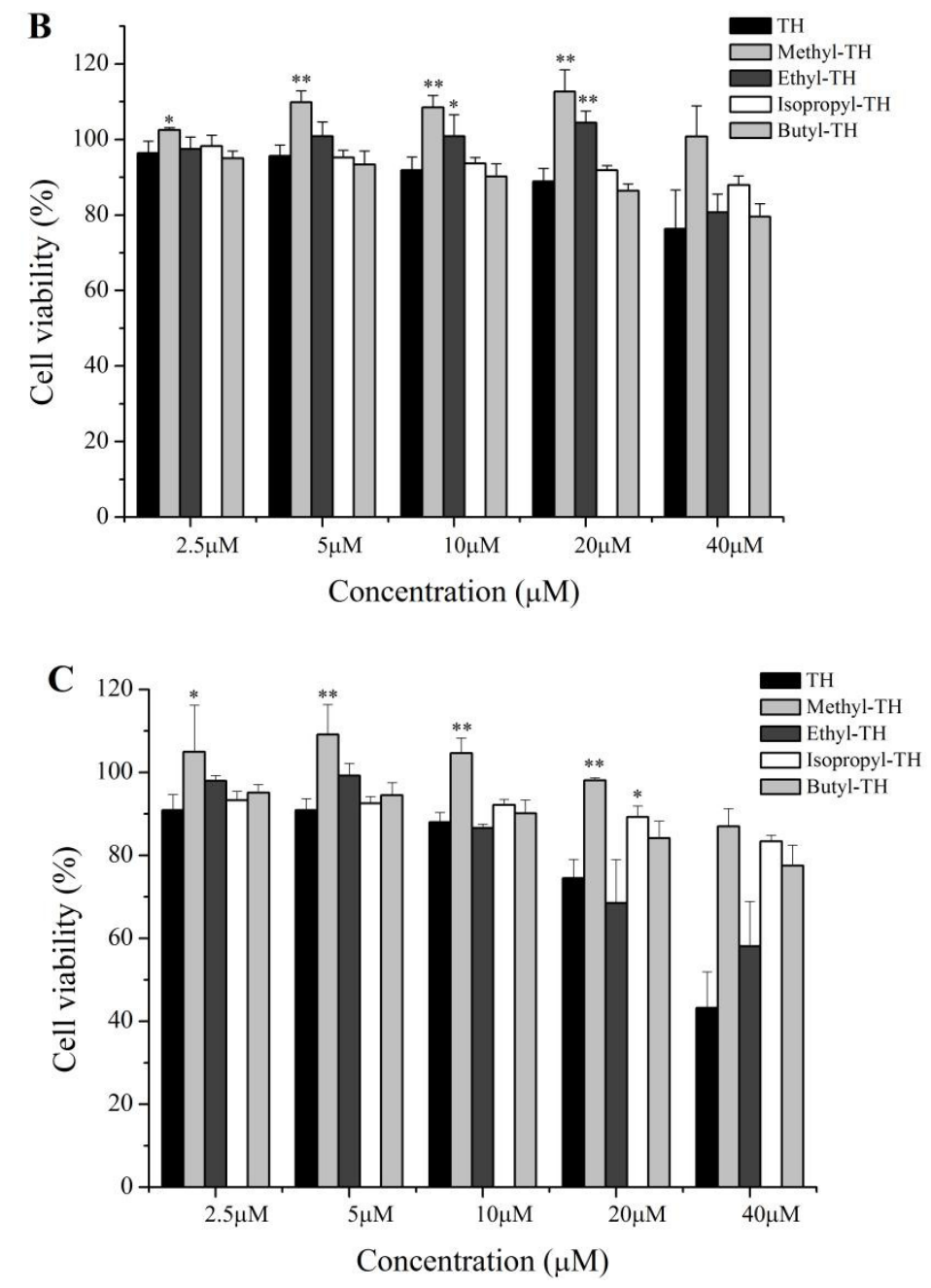

363 by the MTT assay. Data are the mean \pm SD. * indicated $\mathrm{p}<0.05, * *$ indicated $\mathrm{p}<0.01$. (A) pH7.4. (B) pH6.5. (C) pH6.0.

367 In order to get a general view of the toxic profile displayed by TH analogs, the levels of LDH 368 produced in the culture medium were measured at different $\mathrm{pH}$ condition. As shown in Figure 5, 369 the results of the LDH leakage assay were in line with the results of the MTT assay. At $\mathrm{pH} 7.4$, $370 \mathrm{TH}$ and all the modified analogs did not cause a significant release of LDH. The LDH levels 
371 induced by methyl-TH, isopropyl-TH and butyl-TH at $\mathrm{pH} 6.5$ and $\mathrm{pH} 6.0$ were comparable to 372 that at $\mathrm{pH}$ 7.4. LDH levels of $\mathrm{TH}$ and ethyl-TH rose as the $\mathrm{pH}$ value decreased. When the $\mathrm{pH}$
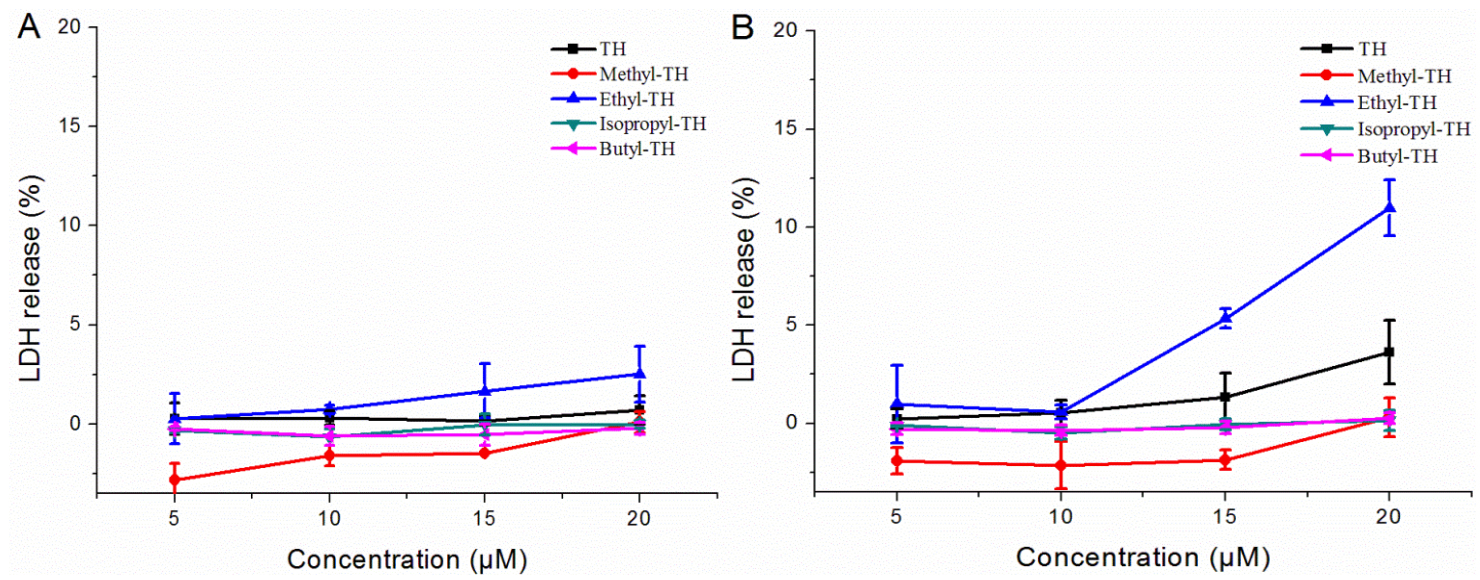

373

374

375

376

377

378

379

380

381

382

value dropped to 6.0, ethyl-TH showed the most obvious $\mathrm{LDH}$ release in comparison with $\mathrm{TH}$ and the other analogs.

Fig5. LDH leakage in Hela cells treated with TH analogs for $2 \mathrm{~h}$ at different pH conditions. (A) pH7.4. (B)pH6.5. (C)pH6.0. $(\mathrm{n}=3$, mean $\pm \mathrm{SD}) .{ }^{*}$ indicated $\mathrm{p}<0.05, * *$ indicated $\mathrm{p}<0.01$

3.5 Hemolysis assay for $\mathrm{TH}$ analogues

To evaluate the safety of $\mathrm{TH}$ analogs in the blood, a hemolysis assay was performed. As shown in Figure 6, TH showed little cytotoxicity against red blood cells and TH analogs also showed remarkably low cytotoxicity in comparison with $\mathrm{TH}$ at the maximum concentration of

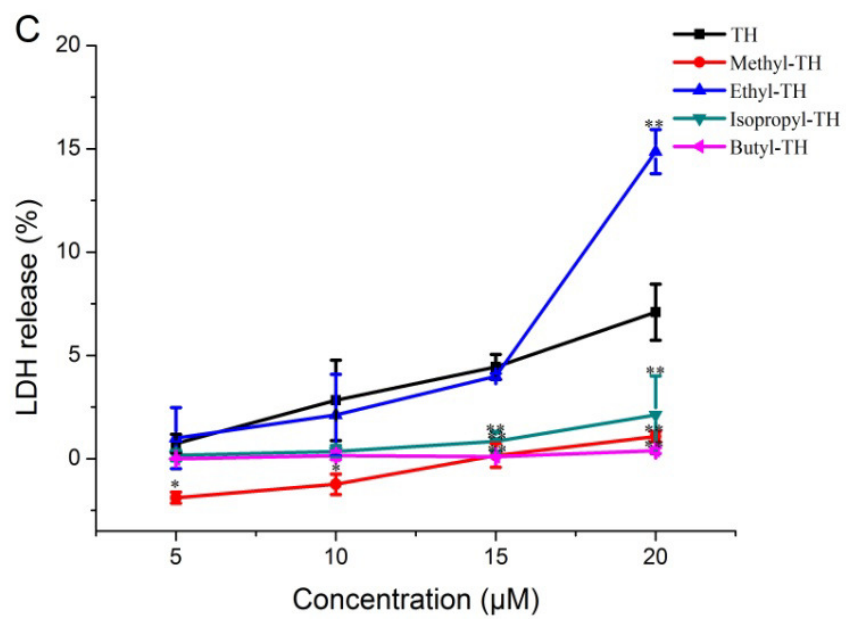




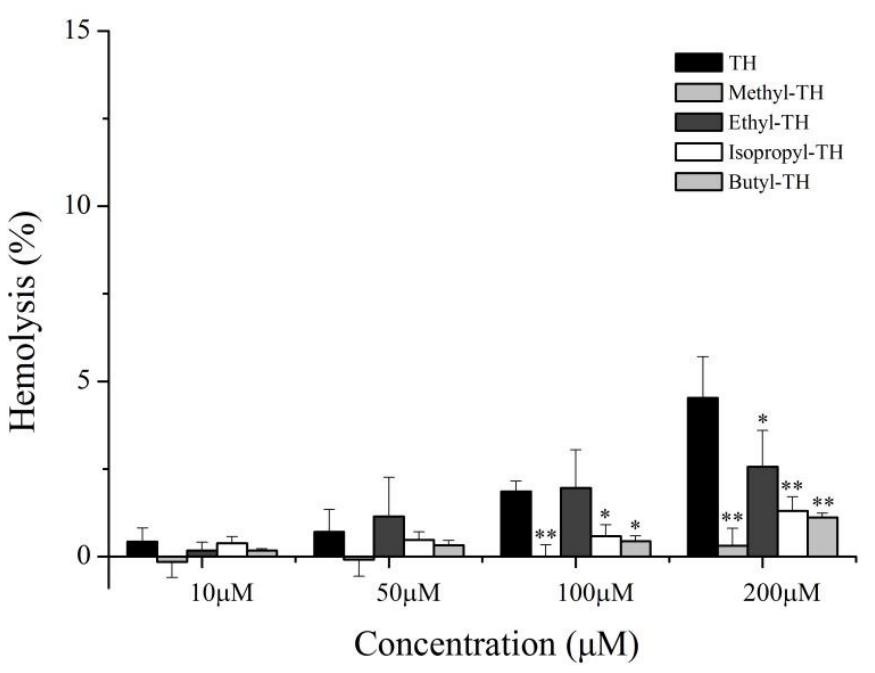

385

Fig.6. Hemolytic activity of TH analogs on mice red blood cells. $(\mathrm{n}=3$, mean $\pm \mathrm{SD}) . *$ indicated $\mathrm{p}<0.05, * *$ indicated $\mathrm{p}<$ 0.01 .

388

\subsection{In vitro antitumor efficacy}

The corresponding analogs were designed to improve the $\mathrm{pH}$-responsive ability of $\mathrm{TH}$. In order to further elucidate the introduced histidine analogs endue $\mathrm{TH}$ with the better $\mathrm{pH}$ responsive capacity at acid tumor microenvironment for elevated cellular uptake and antitumor activity, the new TH analogs were attached to the $20-\mathrm{OH}$ position of CPT by using a disulfide releasable carbonate linker, and the antiproliferation of these CPP-CPT conjugates were evaluated at different $\mathrm{pH}$ conditions in Hela cells. As shown in Figure 7, there was no change in the cytotoxicity and selectivity of isopropyl-TH-CPT in comparison to TH-CPT at all investigated $\mathrm{pH}$ values. In contrast, after $72 \mathrm{~h}$ incubation, the antiproliferative effects of ethylTH-CPT and butyl-TH-CPT in HeLa cells were significantly different at pH 7.4, 6.5 and 6.0. Butyl-TH-CPT in particular showed a remarkably enhanced pH-responsive cytotoxicity at higher concentrations $(10 \mu \mathrm{M}$ and $20 \mu \mathrm{M})$. Moreover, although the cellular uptake level of ethyl-TH 
400 was lower than that of $\mathrm{TH}$ under the same $\mathrm{pH}$ (Figure 1), the cytotoxicity of ethyl-TH-CPT at a 401 concentration of $1.25 \mu \mathrm{M}$ was approximately 3.44- and 3.83- fold higher than that of TH-CPT at $402 \mathrm{pH} 6.5$ and $\mathrm{pH}$ 6.0, respectively. These results demonstrated that, compared with TH-CPT, the 403 cytotoxicity and selectivity of ethyl-TH-CPT and butyl-TH-CPT to cancer cells can be greatly 404 improved. As described above, the $\mathrm{pH}$-responsiveness of the conjugate obtained after histidine 405 isopropylation did not show a noticeable improvement in the $\mathrm{pH}$ range from 7.4 to 6.0. This data 406 was consistent with earlier results demonstrating $\mathrm{pH}$-dependent cellular uptake of TH analogs. 407
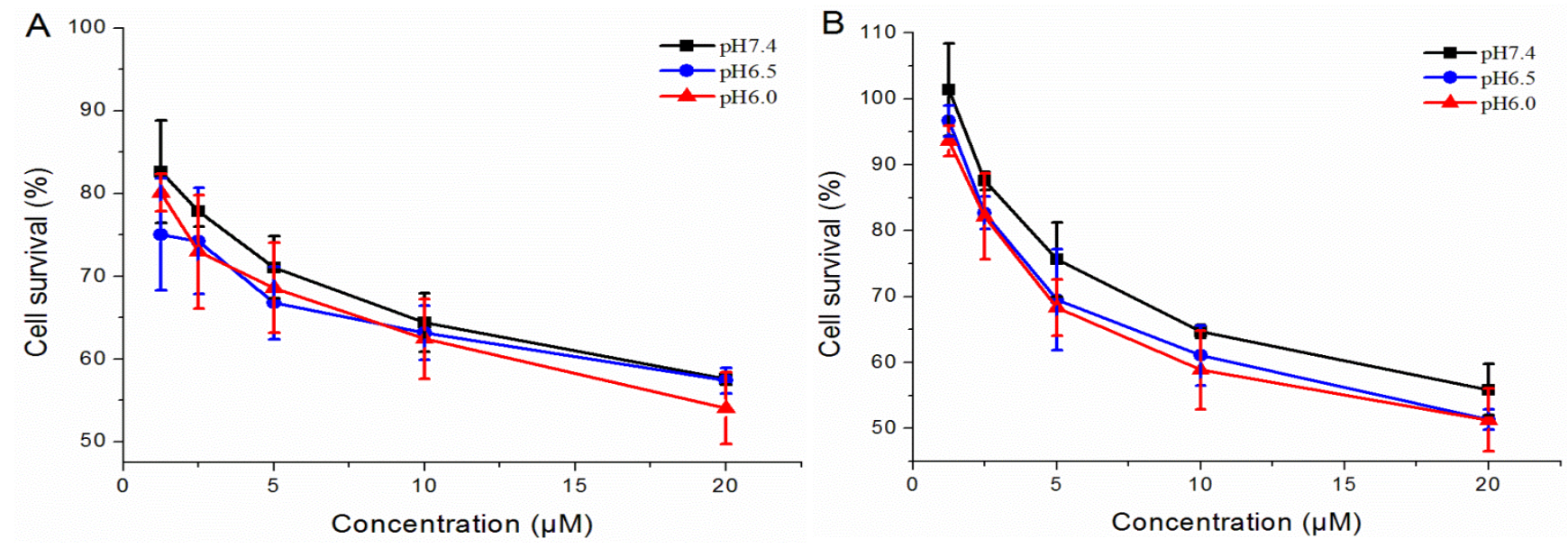

408
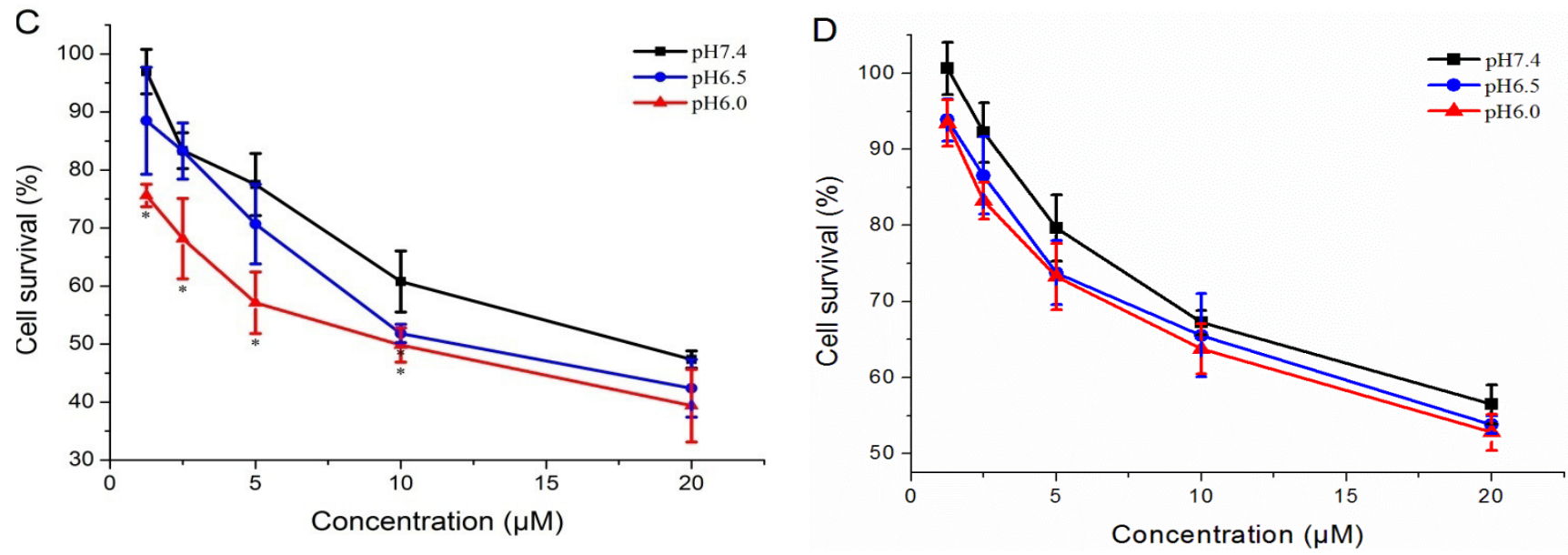


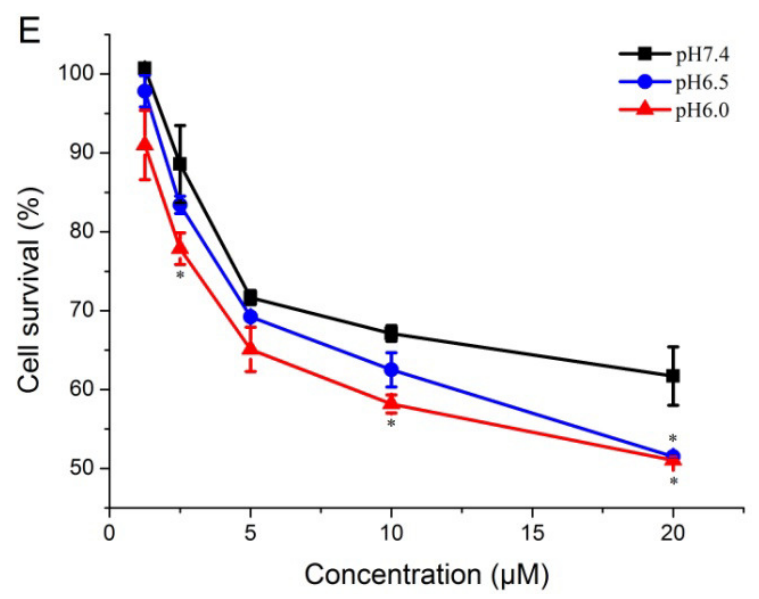

Fig.7. Cytotoxicity of free CPT, TH-CPT and TH analogs-CPT toward Hela cells at different $\mathrm{pH}$ conditions after incubation

4 Discussion

Generally, cationic CPPs can bind on the anionic membrane surfaces via electrostatic interaction and promote cellular uptake(Poon \& Gariepy, 2007). Thus, cationic functionalityis a critical factor for cell penetration. Histidine is especially pH-responsive (Zaro, Fei \& Shen, 2012; Ouahab et al., 2014). Due to the presence of an imidazole ring, it has the ability to receive protons and protonate into a positive charge in an acidic tumor environment, whereas it remains predominantly uncharged under normal physiological conditions. The $\mathrm{pH}$-responsiveness of histidine has been widely utilizedin the design of $\mathrm{pH}$-responsive CPPs for targeted drug delivery. The protonation ability of histidine'simidazole moiety is the key for pH-dependent cellular uptake of histidine-rich peptides. Thus, enhancing the degree of protonation of histidine in histidine-rich peptides will significantly increase their sensitivity to acidic conditions. In this regard, this study focused on the development of new histidine analogs that enhance the protonation of histidine by introducing alkylated groups with different electron-donating ability. 
429 Finally, after the introduction of such modified histidine analogs into $\mathrm{TH}, \mathrm{TH}$ can get protonated 430 more easily and exhibit a higher sensitivity in an acidic environment. In our study, different 431 alkylated groups exhibited varying influence on the $\mathrm{pH}$-response of $\mathrm{TH}$. We found that 432 introducing a methyl group did not improve the pH-responsiveness of TH. Methyl-TH was less 433 hydrophobic than $\mathrm{TH}$, which was confirmed by measuring its retention time on the $\mathrm{C} 18$ reverse434 phase HPLC column (Table 1) (Song et al., 2011). The hydrophobicity of CPPs has been shown 435 to facilitate their membrane translocation (Milletti, 2012; Wada et al., 2013). Clearly, a methyl 436 moiety resulted in a less hydrophobic methyl-TH and in reduction of cellular uptake at all the $\mathrm{pH}$ 437 values.

438

To determine the $\mathrm{pH}$-response of these new analogs and the role of alkyl moiety at the C-2 position of histidine, the cellular uptake of FITC-labeled $\mathrm{TH}$ analogs in HeLa cells was quantified by flow cytometry at various $\mathrm{pH}$. The cellular uptake level of ethyl-TH was lower than that of $\mathrm{TH}$ under the $\mathrm{pH} 7.4$ and 6.5. But the fluorescence intensity of ethyl-TH at $\mathrm{pH} 6.0$ increased substantially, to a quantitative level similar to that of $\mathrm{TH}$ at $\mathrm{pH}$ 6.0. It is shows that ethyl-TH increased its fluorescence intensity much greatly from $\mathrm{pH} 7.4$ and 6.5 to $\mathrm{pH} 6.0$ than TH. This suggested that the $\mathrm{pH}$-responsive effect of ethyl-TH is better than that of $\mathrm{TH}$ at lower $\mathrm{pH}$ values. And the cytotoxicity of ethyl-TH-CPT at a concentration of $1.25 \mu \mathrm{M}$ was approximately 3.44- and 3.83- fold higher than that of TH-CPT at $\mathrm{pH} 6.5$ and $\mathrm{pH}$ 6.0, respectively. These results demonstrated that compared to $\mathrm{TH}$, ethyl-TH and butyl-TH exhibited an improved $\mathrm{pH}$-responsive cellular uptake at $\mathrm{pH} 6.0$ and $\mathrm{pH} 6.5$, respectively. The degree of protonation of histidine at different $\mathrm{pH}$ values was directly correlated with the electron-donating ability of introduced alkylated groups. The longer carbon chain confers upon the alkylated groups an enhanced electron-donating ability, which results in varying histidine protonation at different $\mathrm{pH}$ values and a different $\mathrm{pH}$-response in acidic environments. In addition, the results shows that the change of fluorescence discrepancy of isopropyl-TH from PH7.4 to PH6.0 was lower than that of $\mathrm{TH}$, so isopropyl-modified $\mathrm{TH}$ shows a lower $\mathrm{pH}$-dependent cellular uptake effective. indicating that the $\mathrm{pH}-$ response of isopropyl-TH is worse than that of ethyl-TH and 
456 butyl-TH. The superior acid-responsive effect of ethyl and butyl conjugates, compared with 457 isopropyl conjugates, implies that straight-chain alkyl groups are better in modulating the degree 458 of protonation under acidic conditions in comparison with branched alkyl groups. Accordingly, 459 the alkylated conjugate of $\mathrm{TH}$ is a good representative of novel $\mathrm{TH}$ analogs with optimal pH460 responsive and cellular uptake.

The cytotoxicity of CPPs is positively related to the degree of their positive charge (Jiang et al., 2012; Zhang et al., 2011; Song et al., 2011). This study focused on studying the in vitro cytotoxicity of these $\mathrm{TH}$ analogs. Our results suggested that the $\mathrm{pH}$-responsiveness of ethyl-TH at $\mathrm{pH} 6.0$ is better than that of $\mathrm{TH}$ and all the other $\mathrm{TH}$ analogs. The possible reason for this might be that easier protonation of ethyl-TH can increase the intensity of positive charge at $\mathrm{pH}$ 6.0 , thereby resulting in higher cytotoxicity of ethyl-TH at higher concentrations. Accordingly, after alkylation, TH still exhibited slight cytotoxicity at physiological $\mathrm{pH}$.

The safety of the drug vector is a vital aspect in any pharmaceutical application. In this study, we also performed a hemolysis assay for all $\mathrm{TH}$ analogues. The results of the assay suggested improved relative safety of TH analogs. It was reported that cationic CPPs may cause cell lysis and systemic toxicity (Jiang et al., 2012;Zorko \& Langel,2005) when used as delivery vectors, which restricts their successful in vivo utilization. Due to the loss of cationic charge at physiological $\mathrm{pH}$, histidine-containing $\mathrm{TH}$ exhibited little cytotoxicity to normal cells, which is in agreement with previous literature (Zhang et al., 2011). Interestingly, after histidinealkylation, the new TH analogs exhibited relatively lower cytotoxicity at higher concentrations, suggesting a smaller degree of perturbation with the negatively charged membrane of erythrocytes. In comparison, the diminished cytotoxicity of new TH analogs to normal blood cells implied their safety as vectors for targeted drug delivery.

In general, the principal drawback of clinical conventional anticancer agents is their lack of specificity, leading to undesirable side effects. It has been reported that the acidic tumor microenvironment is one of the major obstacles for efficient drug delivery, and that there is a 
482

483

484

485

486

487

488

489

490

491

492

493

494

495

496

497

498

499

500

501

502

503

504

505

506

need for $\mathrm{pH}$-responsive vectors for anticancer drugs (Shen et al., 2012). The pH-sensitive, cell penetrating ability of $\mathrm{TH}$ makes it suitable for targeted drug delivery to tumor cells with an acidic extracellular environment. The results of our study strongly demonstrated that, compared with TH-CPT, the cytotoxicity and selectivity of ethyl-TH-CPT and butyl-TH-CPT is greatly improved. Meanwhile, the pH-responsiveness of isopropyl histidine conjugates, did not show a noticeable improvement, but was consistent with the earlier results demonstrating a $\mathrm{pH}-$ dependent cellular uptake of TH analogs. In comparison with isopropyl-TH-CPT, ethyl-TH-CPT and butyl-TH-CPT exhibited a desirable $\mathrm{pH}$-sensitivity to tumor cells. Therefore, after histidine modification, the improved $\mathrm{pH}$-responsiveness of $\mathrm{TH}$ makes it suitable as a vector for targeted CPT delivery to tumor tissues with an acidic tumor microenvironment.

\section{Conclusion}

In this paper, by introducing electron donating groups to the histidine imidazole ring of TH, we developed a new type of acid-responsive CPP with a high sensitivity to the acidic tumor microenvironment and low toxicity under physiological conditions. This work opens a new avenue for designing preeminent $\mathrm{pH}$-responsive CPPs, which could easily translocate into cells under weakly acidic conditions. The new TH analogs with modified histidine could easily protonate into a positive charge in a weakly acid microenvironment due to the introduction of electron donating groups. As a result, these TH analogs could deliver more CPT to the tumor cells and show excellent antitumor effects in an acidic extracellular environment, in comparison with TH-CPT and free CPT. These properties render the $\mathrm{TH}$ analogs we designed and synthesized suitable and superior as $\mathrm{pH}$-sensitive, vectors for targeted antitumor drug delivery with low toxicity. In view of this, $\mathrm{TH}$ analogs provided us with a new perspective on the development of $\mathrm{pH}$-sensitive, CPP-modified drug delivery systems.

\section{References}

[1] Chari RVJ. Targeted cancer therapy: conferring specificity to cytotoxic drugs. AccChem Res. 41(2008)98-107. 
507 [2] Monsuez J J, Charniot J C, Vignat N, JY Artigou. Cardiac side-effects of cancer chemotherapy. International Journal of Cardiology. 144(1)(2010)3-15.

509

510

511

[3] Michelle M, J Rg D. Cognitive side effects of cancer therapy demonstrate a functional role for adult neurogenesis. Behavioural Brain Research. 227(2)(2012)376-9.

[4] Dinca Ana, Chien Wei-Ming, Chin Michael T. Intracellular Delivery of Proteins with Cell-Penetrating Peptides for Therapeutic Uses in Human Disease. International Journal of Molecular Sciences. 17(2)(2016)263.

[5] Kato T, Yamashita H, Misawa T, Nishida K, Kurihara M, Tanaka M, Demizu Y, Oba M. Plasmid DNA delivery by argininerich cell-penetrating peptides containing unnatural amino acids. Bioorganic \& Medicinal Chemistry. 24(2016)2681-2687.

[6] Helmfors H, Eriksson J, ÜloLangel. Optimized luciferase assay for cell-penetrating peptide-mediated delivery of short oligonucleotides. Analytical Biochemistry. 484(2015)136-142.

[7] Huang YZ, Jiang YF, Wang HY, Wang J, Shin MC. Curb challenges of the "Trojan Horse" approach: smart strategies in achieving effective yet safe cell-penetrating peptide-based drug delivery. Adv Drug Deliver Rev. 65(2013)1299-1315.

[8] Vivès E, Schmidt J, Pèlegrin A. Cell-penetrating and cell-targeting peptides in drug delivery. Biochim.Biophys.Acta. 1786(2008)126-138.

[9] Fonseca SB, Pereira MP, Kelley SO. Recent advances in the use of cell-penetrating peptides for medical and biological applications. Adv. Drug Deliv. Rev. 61(2009)953-964.

[10] Davoudi Z, Akbarzadeh A, Rahmatiyamchi M, Movassaghpour AA, Alipour M, Nejati-Koshki.K, Sadeghi Z, Dariushnejad.H, Zarghami.N. Molecular target therapy of AKT and NF-kB signaling pathways and multidrug resistance by specific cell penetrating inhibitor peptides in HL-60 cells. Asian Pacific Journal of Cancer Prevention Apjcp. $15(10)(2014) 4353-8$.

[11] Vargas J R, Stanzl E G, Teng N N H, Wender PA. Cell-Penetrating, Guanidinium-Rich Molecular Transporters for Overcoming Efflux-Mediated Multidrug Resistance. Molecular Pharmaceutics. 11(8)(2014)2553-2565.

[12] Dubikovskaya EA, Thorne SH, Pillow TH, Contag CH, Wender PA. Overcoming multidrug resistance of small-molecule therapeutics through conjugation with releasable octaarginine transporters. Proc. Natl. Acad. Sci. U. S. A. 105(2008)12128- 
[13] Lindgren M, Rosenthal-Aizman K, Saar K, Eiríksdóttir E, Jiang Y, Sassian M, Ostlund P, Hällbrink M, Langel U.Overcoming methotrexate resistance in breast cancertumour cells by the use of a new cell-penetrating peptide. Biochem.Pharmacol. 71(2006)416-425.

[14] Lee ES, Gao Z, Bae YH. Recent progress in tumor pH targeting nanotechnology. J.Control Release. 132(2008)164-170.

[15] Shi KR, Li JP, Gao ZL, Yang P, Qiu Y, Yang B, Wang Y, Long Y, Liu Y, Zhao Q, Qian J, Zhang Z, Gao H, He Q. A pHresponsive cell-penetrating peptide-modified liposomes with active recognizing of integrin $a_{v} \beta 3$ for the treatment of

[16] Jiang TY, Zhang ZH, Zhang YL, Lv HW, Zhou JP, Li CC, Hou LL, Zhang Q. Dual-functional liposomes based on pHresponsive cell-penetrating peptide and hyaluronic acid for tumor-targeted anticancer drug delivery. Biomaterials.

[17] Fei LK, Yap LP, Conti PS, Shen WC, Zaro JL. Tumor targeting of a cell penetrating peptide by fusing with a pH-sensitive 33(2012)9246-9258.

[18] I.F.Tannockand, D.Rotin. Acid pH in tumors and its potential for therapeutic exploitation. Cancer Res. 49 (1989) 4373-4384.

[19] Jähde E, Rajewsky M F, Baumgärtl H. pH distributions in transplanted neural tumors and normal tissues of BDIX rats as measured with pH microelectrodes. Cancer Research. 42(4)(1982)1498-504.

[20] Cardone R.A, Casavola V, Reshkin S.J. The role of disturbed $\mathrm{pH}$ dynamics and the $\mathrm{Na}+\mathrm{H}+$ exchanger in metastasis. Nature Reviews Cancer. 5(10)(2005)786-795.

[21] Liang J, Wu WL, Xu XD, Zhuo RX, Zhang XZ. pH Responsive micelle self-assembled from a new amphiphilic peptide as anti-tumor drug carrier. Colloid \& Surface B Biointerfaces. 114(2014) 398-403.

[22] Han SS, Li ZY, Zhu JY, Zhang XZ. Dual-pH sensitive charge-reversal polypeptide micelles for tumor-triggered targeting uptake and nuclear drug delivery. Small. 11(2015)2543-2554.

[23] Ziegler A. Thermodynamic studies and binding mechanisms of cell-penetrating peptides with lipids andglycosaminoglycans. Adv. Drug Deliv. Rev. 60(2008)580-597. 
555 [24] Guo Z, Peng H, Kang J. Cell-penetrating peptides: Possible transduction mechanisms and therapeutic applications (Review). Biomedical Reports. 4(5)(2016) 528-534.

557

[25] Futaki S, Nakase I, Tadokoro A, Takeuchi T, Jones AT. Arginine-rich peptides and their internalization mechanisms. Biochemical Society Transactions. 35(Pt 4)(2007) 784-7.

[26] Zaro JL, Fei L, Shen WC. Recombinant peptide constructs for targeted cell penetrating peptide-mediated delivery. J. Control Release. 158(2012) 357-361.

[27] Zhang W, Song JJ, Zhang BZ, Liu LW, Wang KR, Wang R. Design of acid-activated cell penetrating peptide for delivery of active molecules into cancer cells. Bioconjugate Chem. 22(2011) 1410-1415.

[28] Ouahab A, Cheraga N, Onoja V, Shen Y, Tu J. Novel pH-sensitive charge-reversal cell penetrating peptide conjugated PEGPLA micelles for docetaxel delivery: in vitro study. International Journal of Pharmaceutics. 466(1-2)(2014) 233-245.

[29] Qian W, Liu F, Burke T.R. Investigation of Unanticipated Alkylation at the N( $\pi$ ) Position of a HistidylResidue Under Mitsunobu Conditions and Synthesis of Orthogonally Protected Histidine Analogues. Journal of Organic Chemistry. $76(21)(2011) 8885-90$.

[30] Henne W.A, Doorneweerd D.D, Hilgenbrink A.R. Synthesis and activity of a folate peptide camptothecinprodrug. Bioorganic \& Medicinal Chemistry Letters. 16(20)(2006)5350-5.

[31] G.M. Poon, J. Gariepy. Cell-surface proteoglycans as molecular portals for cationic peptide and polymer entry into cells, Biochem. Soc. Trans. 35 (2007) 788-793.

[32] Song JJ, Kai M, Zhang W, Zhang JD, Liu LW, Zhang BZ, Liu X, Wang R. Cellular uptake of transportan 10 and its analogs in live cells: Selectivity and structure-activity relationship studies. Peptides. 32(2011)1934-1941.

[33] F. Milletti. Cell-penetrating peptides: classes, origin, and current landscape. Drug Discov Today. 17(2012) 850-860.

[34] Wada S, Hashimoto Y, Kawai Y, Miyata K, Tsuda H, Nakagawa O, Urata H. Bioorg Med Chem. 21(2013)7669-7673.

[35] Schinwald A, Murphy F A, Jones A, W Macnee, K Donaldson. Graphene-Based Nanoplatelets: A New Risk to the Respiratory System as a Consequence of Their Unusual Aerodynamic Properties. Acs Nano. 6(1)(2012)736-46. 
578 [36] Zorko M, LangelÜ. Cellpenetrating peptides: mechanism and kinetics of cargo delivery. Adv Drug Deliver Rev. $57957(4)(2005) 529-545$.

580 [37] Shen M, Huang Y, Han L, Qin J, Fang X. Multifunctional drug delivery system for targeting tumor and its acidic 581 microenvironment. Journal of Controlled Release Official Journal of the Controlled Release Society. 161(3)(2012):884-92. 